\title{
Specific Power of Liquid-Metal-Cooled Reactors
}

Dean Dobranich

Prepared by

Sandia National Laboratories

Albuquerque, New Mexico 87185 and Livermore, California 94550

for the United States Department of Energy

under Contract DE-AC04-76DP00789 
Issued by Sandia National Laboratories, operated for the United States Department of Energy by Sandia Corporation.

NOTICE: This report was prepared as an account of work sponsored by an agency of the United States Government. Neither the United States Government nor any agency thereof, nor any of their employees, nor any of their contractors, subcontractors, or their employees, makes any warranty, express or implied, or assumes any legal liability or responsibility for the accuracy, completeness, or usefulness of any information, apparatus, product, or process disclosed, or represents that its use would not infringe privately owned rights. Reference herein to any specific commercial product, process, or
service by trade name, trademark, manufacturer, or otherwise, does not service by trade name, trademark, manufacturer, or otherwise, does not by the United States Government, any agency thereof or any of their by the United States Government, any agency thereof or any of their
contractors or subcontractors. The views and opinions expressed herein do not necessarily state or reflect those of the United States Government, any agency thereof or any of their contractors or subcontractors.

Printed in the United States of America Available from

National Technical Information Service

U.S. Department of Commerce

5285 Port Royal Road

Springfield, VA 22161

NTIS price codes

Printed copy: A03

Printed copy: A03
Microfiche copy: A01 
SAND87-2067

Unlimited Release

Printed October 1987

Distribution

Category UC-80

\begin{abstract}
SPECIFIC POWER OF LIQUID-METAL-COOLED REACTORS
\end{abstract}
Dean Dobranich

Advanced Nuclear Power Systems Safety Division

Sandia National Laboratories

Albuquerque, New Mexico 87185

\begin{abstract}
Calculations of the core specific power for conceptual space-based liquid-metal-cooled reactors, based on heat transfer considerations, are presented for three different fuel types: (1) pin-type fuel, (2) cermet fuel, and (3) thermionic fuel. The calculations are based on simple models and are intended to provide preliminary comparative results. The specific power is of interest because it is a measure of the core mass required to produce a given amount of power. Potential problems concerning zero-g critical heat flux and loss-of-coolant accidents are also discussed because these concerns may limit the core specific power. Insufficient experimental data exists to accurately determine the critical heat flux of liquid-metal-cooled reactors in space; however, preliminary calculations indicate that it may be a concern. Results also indicate that the specific power of the pin-type fuels can be increased significantly if the gap between the fuel and the clad is eliminated. Cermet reactors offer the highest specific power because of the excellent thermal conductivity of the core matrix material. However, it may not be possible to take full advantage of this characteristic when loss-of-coolant accidents are considered in the final core design. The specific power of the thermionic fuels is dependent mainly on the emitter temperature. The small diameter thermionic fuels have specific powers comparable to those of pin-type fuels.
\end{abstract}




\section{ACKNOWLEDGMENTS}

The author would like to thank Albert Marshall, Vincent Dandini, and Steve Webb for their comments concerning this work. 
CONTENTS

page

ABSTRACT $\ldots \ldots \ldots \ldots \ldots \ldots \ldots \ldots \ldots \ldots \ldots \ldots \ldots \ldots \ldots \ldots \ldots$

ACKNOWLEDGMENTS $\ldots \ldots \ldots \ldots \ldots \ldots \ldots \ldots \ldots \ldots \ldots \ldots$ ii

1.0 INTRODUCTION $\ldots \ldots \ldots \ldots \ldots \ldots \ldots \ldots \ldots \ldots \ldots \ldots \ldots \ldots \ldots$

2.0 SPECIFIC POWER FORMULAE ................. 2

2.1 Pin-Type Fuel $\ldots \ldots \ldots \ldots \ldots \ldots \ldots \ldots \ldots \ldots \ldots \ldots \ldots . \ldots \ldots$

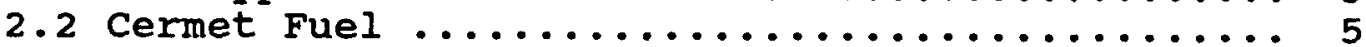

2.3 Thermionic Fuel ..................... 8

3.0 HEAT TRANSFER COEFFICIENTS ................ 10

4.0 SPECIFIC POWER CALCULATIONS ................ 12

5.0 CRITICAL HEAT FLUX CONCERNS ................. 19

6.0 LOSS-OF-COOLANT CONCERNS $\ldots \ldots \ldots \ldots \ldots \ldots \ldots \ldots \ldots \ldots$

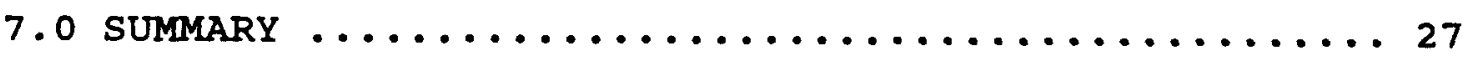

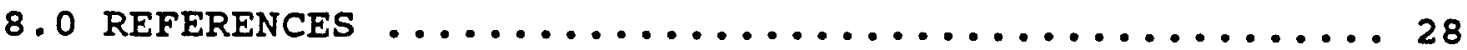




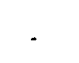




\subsection{INTRODUCTION}

Liquid-metal-cooled nuclear reactors have been proposed for use in outer space to supply tens of megawatts of thermal power for the production of electricity to power various defense-related space platforms. An item of concern for any space-based component is its weight because of the associated high launch costs. Thus, the determination of the weight required by a reactor core to produce a given amount of power is a parameter of interest. A measure of this parameter is the specific power defined as the maximum amount of power a unit mass of fuel can produce for a particular set of operating conditions. The RSMASS code [1] is used to provide estimates of the reactor and shield masses for space-based nuclear reactors. one of the required input variables for RSMASS is the specific power (MW $/ \mathrm{kg}-\mathrm{U})$ of the reactor. Recently completed thermal hydraulic analyses $[2,3]$ provided estimates of specific power for several gas-cooled reactors. A similar analysis has been carried out for liquid-metal-cooled reactors and the results of this analysis are reported in this report. The analysis was performed for three types of fuels: (1) pin-type fuel, (2) cermet fuel, and (3) thermionic fuel. The effect of critical heat flux constraints is also addressed along with a simple analysis of a loss-of-coolant accident and its possible impact on the specific power. 


\section{O SPECIFIC POWER FORMULAE}

With respect to heat transfer, the specific power for the liquid-metal-cooled reactors is a function of the thermal resistances associated with core components such as the fuel, the gap, the fuel cladding or coating, and the coolant. With the coolant and the maximum-allowed fuel temperatures specified, the specific power, $\mathrm{P}_{\mathbf{S}}$, can be expressed as:

$$
P_{s}=\left(T_{f}-T_{c}\right) /\left(\rho_{f} P_{z} P_{r} \sum_{i=1}^{n} R_{i}\right)
$$

where: $T_{f}=$ maximum-allowed fuel temperature,

$\mathbf{T}_{\mathbf{C}}=$ coolant bulk temperature (or fuel surface temperature) at fuel hot spot,

$\rho_{f}=$ fuel density,

$\mathrm{P}_{\mathrm{Z}}=$ axial peak-to-average power factor,

$\mathbf{P}_{\mathbf{r}}=$ radial peak-to-average power factor,

$\mathbf{n}=$ the number of core thermal resistances, and

$\mathbf{R}_{\mathbf{i}}=$ the $i^{\text {th }}$ thermal resistance.

The thermal resistances were derived for this work on a unit volume basis as opposed to a unit area basis as is commonly found in the heat transfer literature. This was done because the quantity of interest (the specific power) is determined as the fuel volumetric heat generation rate divided by the fuel density. Therefore, expressing the resistances on a volume basis is consistent with the objective of this work and makes the evaluation of equation (1) straightforward.

If a cosine axial power profile is assumed, the coolant bulk temperature at the fuel hot spot can be estimated as the algebraic average of the core inlet and outlet coolant temperatures. For a flat axial profile, the core outlet coolant temperature should be used. If a boiling coolant is used, then the saturation temperature provides a good estimate of the coolant bulk temperature.

Several multimegawatt space reactor concepts have been proposed that use a liquid metal to provide core cooling. In some concepts, the metal remains a liquid as it passes through the core while other concepts make use of boiling liquid-metal coolant. Three basic fuel types have been proposed for the liquid-metal-cooled reactors: (1) pin-type fuel in which the fuel is in the form of clad fuel pins, (2) cermet fuel in which a ceramic fuel resides in a metal matrix material such as tungsten, and (3) thermionic fuel in which the fuel is in the form of clad hollow cylindrical pins. In the pin-type fuel, coolant flows within the space between the fuel rods. In the cermet fuel, the coolant flows either axially or radially through channels formed within the matrix material. In the thermionic fuel, coolant flows around a collector that surrounds 
the hollow pin. (The hole in the fuel pin provides volume for the collection of fission products and the outer surface of the cladding is the thermionic emitter.)

The formulae used to determine specific power for the three types of fuels are presented in the next three subsections.

\subsection{Pin-Type Fuel}

A schematic diagram of the pin-type fuel is given in Figure 2.1.1. A liner material is shown between the fuel and the gap. The thermal resistance for the liner should be neglected if a liner is not used for a particular concept. The thermal resistances, $R$, associated with the pin-type geometry are as follows:

fuel

pin:

$$
R_{f}=r_{1}^{2} / 4 k_{f}
$$

liner:

$$
R_{1}=r_{1}^{2} \ln \left(r_{2} / r_{1}\right) / 2 k_{1}
$$

gap:

$$
R_{g}=r_{1}^{2} / 2 r_{2} h_{g}
$$

clad:

$$
R_{c l}=r_{1}^{2} \ln \left(r_{4} / r_{3}\right) / 2 k_{c l}
$$

coolant:

$$
R_{c}=r_{1}^{2} / 2 r_{4} h_{c}
$$

where; $r=$ radius,

$h=$ heat transfer coefficient, and

$k=$ thermal conductivity. 


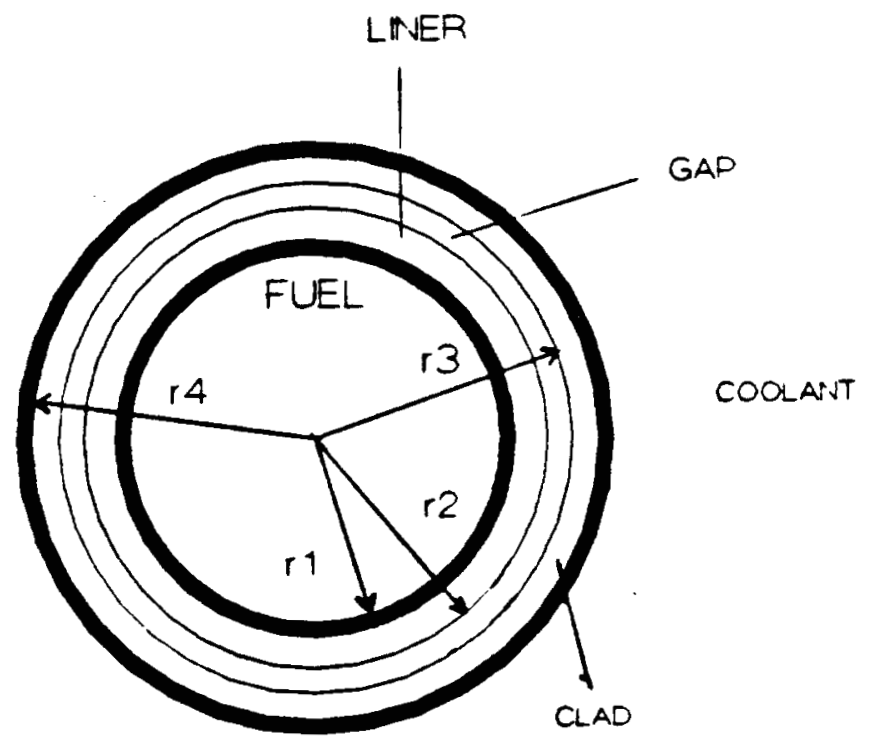

Figure 2.1.1 Pin-Type Fuel Schematic 


\subsection{Cermet Fuel}

A schematic diagram of the cermet fuel type is given in Figure 2.2.1. The expressions for the thermal resistances associated with this fuel type are not straightforward because the fuel is dispersed within the matrix material either as a composite or as coated spherical particles. If the fuel is dispersed as a composite, the resistances associated with the particle and coating do not apply. The distance $s$, as shown in Figure 2.2.1, is the maximum distance that heat must travel from the fuel to the coolant channel wall. A fuel particle is assumed to reside at this location to provide a conservative estimate (worst case) of the matrix and particle temperature differences. Because the fuel is uniformly dispersed within the matrix material, the matrix is assumed to have a uniform volumetric heat generation rate. An estimate of the matrix temperature drop across the distance $s$ can be made by using the conduction relation for heat flow in a hollow cylinder of inside radius equal to the channel radius and outside radius equal to the inside radius plus the distance $S$. Assuming circular channels of constant flow area, the resistances are as follows:

fuel

particle:

$$
R_{\text {par }}=d_{\text {par }}{ }^{2} / 24 k_{f}
$$

coating:

$$
R_{c t}=t d_{p a r^{2}} /\left[12 k_{c t}\left(d_{p a r} / 2+t\right)\right]
$$

matrix:

$$
R_{m}=\left[G\left(S+d_{c}\right)^{2}-B / 2\right] f V_{f} / 2 k_{m}
$$

coolant:

$$
\begin{aligned}
& R_{C}=B f V_{f} / h_{C} d_{c h} \\
& \text { with; } G=\ln \left[\left(2 s+d_{c h}\right) / d_{c h}\right] \\
& B=\left[\left(s+d_{c h} / 2\right)^{2}-\left(d_{c h} / 2\right)^{2}\right]
\end{aligned}
$$

where; $v_{f}=$ fuel volume fraction

$$
\begin{aligned}
& f^{f}=\text { geometry correction factor } \\
& s=\text { maximum matrix conduction length, } \\
& t=\text { coating thickness, and } \\
& d=\text { diameter. }
\end{aligned}
$$

As previously mentioned, the maximum matrix conduction length, $S$, is the maximum distance that heat must travel from the fuel to the coolant channel wall and depends on the number and diameter of the channels, and whether the channels are arranged on a triangular or square array. Figure 2.2.1 provides examples of these two arrangements. The area bounded by the circle of diameter $d_{c h}+2 s$ represents the unit cell for the 
heat conduction calculations. The geometric unit cell is shown as a hexagon for the triangular array and as a square for the square array.

The geometry correction factor, $f$, accounts for the fact that the conduction unit cell volume is larger than the geometric unit cell volume. The geometric correction factor can be calculated as the cross-sectional area of the geometric unit cell (not including the channel area) divided by the cross-sectional area of the conduction unit cell (again, not including the channel area). In dealing with reactor concepts, $f$ will in general not be known because it depends on the number and spacing of the channels. However, $f$ will be less than 1.0 , and using $f$ equal to 1.0 results in a conservative estimate of specific power; $i . e .$, the actual specific power will be somewhat larger.

The fuel volume fraction, $v_{f}$, is defined as the volume of fuel divided by the volume of matrix material. This is a measure of the fuel loading within the core and must be based not only on specific power constraints but also on criticality constraints. Lower values of $v_{f}$ result in higher values of specific power. 

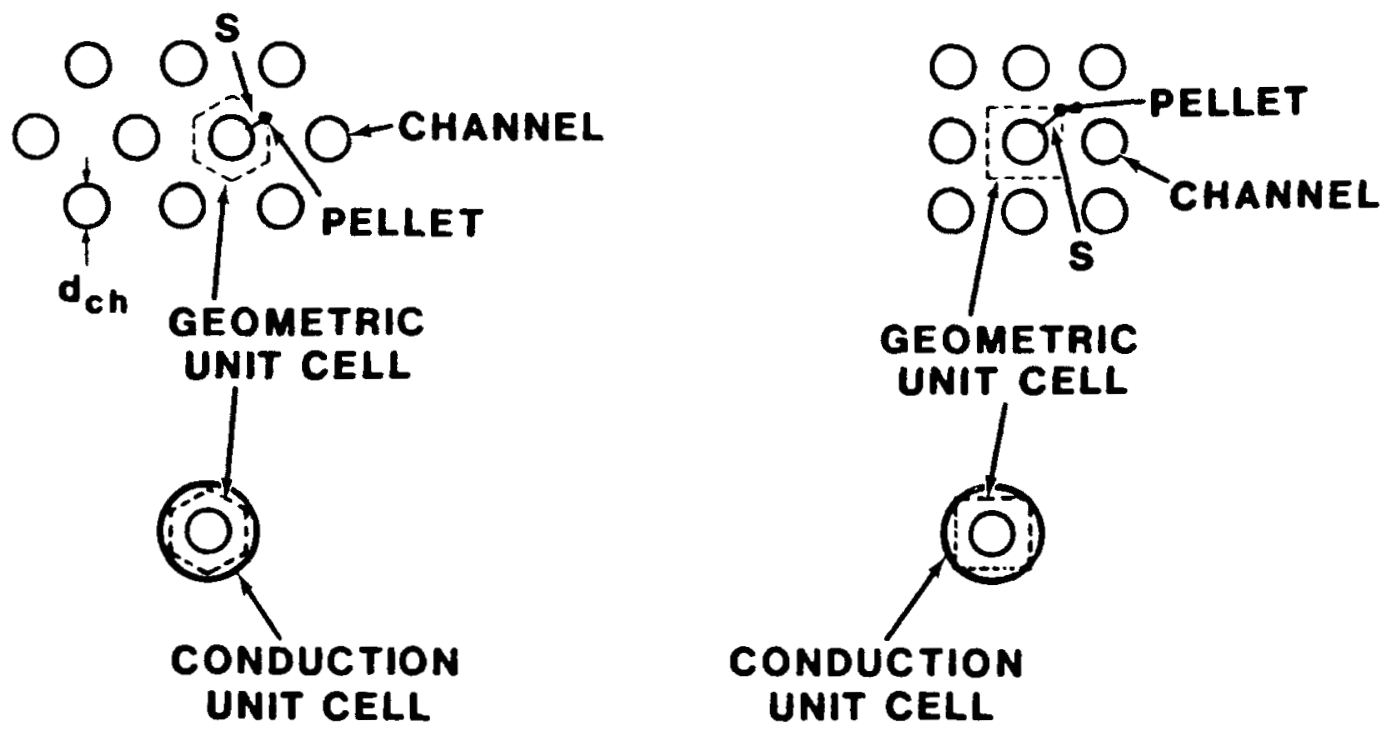

Figure 2.2.1 Matrix Fuel Schematic

(Triangular and Square Arrays) 


\subsection{Thermionic Fuel}

A schematic of the thermionic fuel is shown in Figure 2.3.1. Thermionic fuel produces electric power by "boiling" electrons off the surface of an emitter material; the electrons are then collected on a collector surface. There is a gap between the emitter and collector surfaces, and the collector is surrounded by the coolant. For the thermionic fuel, the outer clad surface as shown in the figure is the emitter. The emitter temperature defines the operating characteristics of the thermionic fuel and is assumed to be specified for the specific power calculations. Therefore, the collector and coolant temperatures do not enter into the specific power calculations; only the maximum-allowed fuel temperature (at radius $r_{1}$ ) and the emitter temperature (at radius $r_{3}$ ) are needed. The thermal resistances for the thermionic fuel are:

fuel

pin:

$$
R_{f}=\left[\left(r_{2}{ }^{2}-r_{1}{ }^{2}\right) / 2-r_{1}{ }^{2} \ln \left(r_{2} / r_{1}\right)\right] /\left(2 k_{f}\right)
$$

clad:

$$
R_{c l}=\left(r_{2}^{2}-r_{1}^{2}\right) \ln \left(r_{3} / r_{2}\right) /\left(2 k_{c l}\right)
$$

where; $\mathbf{r}=$ radius, and

$k=$ thermal conductivity. 


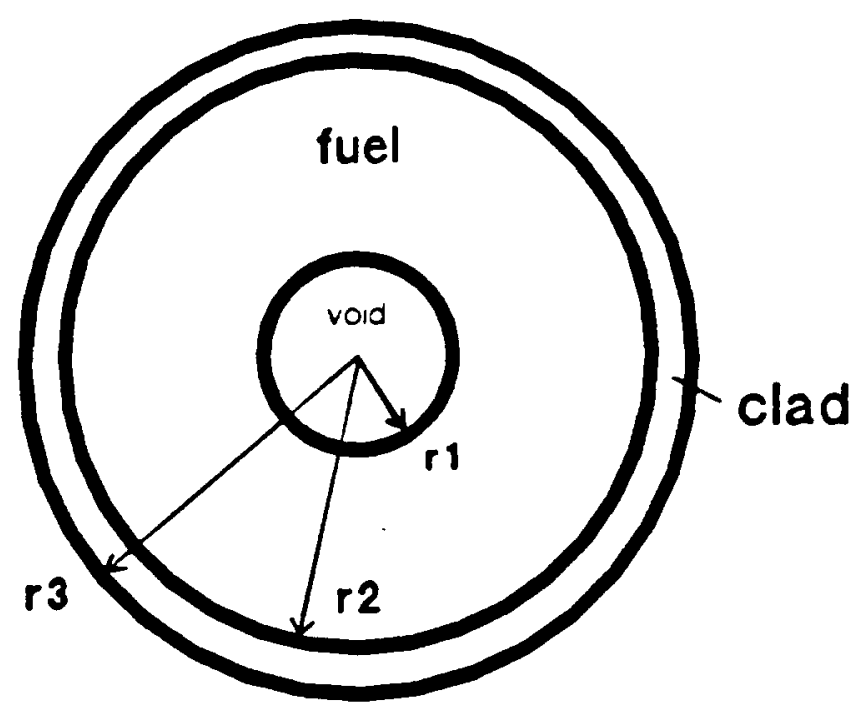

Figure 2.3.1 Thermionic Fuel Schematic 


\subsection{HEAT TRANSFER COEFFICIENTS}

To calculate the thermal resistances, values for the various parameters appearing in the resistance formulae must be provided. The parameters consist of (1) dimensions, which are related to the core geometry, (2) thermal conductivities, which are related to the materials used in the core, and (3) the heat transfer coefficients for the gap and the coolant. The gap and coolant heat transfer coefficients are addressed in this section.

For liquid-metal-cooled reactors with pin-type fuel, the thermal resistance associated with the gap is larger than the other thermal resistances and therefore dominates the specific power limit. The gap heat transfer coefficient (or gap conductance) increases with burnup and is lowest at the beginning of core life. For light water reactors, the gap conductance, $\mathrm{h}_{\mathrm{g}}$, varies between about 5,000 and 30,000 $\mathrm{W} / \mathrm{m}^{2} / \mathrm{K}$ over the life of the fuel. For liquid-metal-cooled fast reactors, $h_{g}$ varies between approximately 3,000 and 20,000 $\mathrm{W} / \mathrm{mq} \cdot \mathrm{m} / \mathrm{K} \quad[4]$. Because the thermal resistance associated with the gap is relatively large and because $h_{g}$ varies over a wide range, $\mathrm{h}_{\mathrm{g}}$ is best treated parametrically for conceptual reactors.

For forced convection to single-phase liquid metals, there is a wealth of heat transfer coefficient data available in the literature. Typically, the heat transfer coefficient ranges from 20,000 to $60,000 \mathrm{w} / \mathrm{m}^{2} / \mathrm{K}$ [5]. A popular correlation [5] for liquid-metal single-phase forced convection heat transfer is:

$$
\mathrm{Nu}=7.0+0.025 \mathrm{Pe}^{0.8}
$$

where; $\mathrm{Nu}=$ Nusselt number, and

$\mathrm{Pe}=$ Peclet number.

Numerous correlations for liquid-metal pool boiling are also available [6]. However, there are very few correlations available for forced convection boiling, and the uncertainties associated with the available correlations are large. $A$ correlation for forced convection liquid-metal boiling [7] is given by:

$$
h=0.204\left[L\left(x_{n}-2 x_{l}\right)\right]^{0.7} p^{0.15}(G d / 1)^{0.7}
$$

where; $h=$ heat transfer coefficient $\left[\mathrm{W} / \mathrm{m}^{2} / \mathrm{k}\right]$,

$I=$ latent heat of evaporation $[\mathrm{J} / \mathrm{kg}]$,

$x_{n}=$ exit quality,

$x_{1}=$ subcooled inlet vapor quality,

$p^{1}=$ pressure $\left[\mathrm{N} / \mathrm{m}^{2}\right]$,

$G=$ mass flow per unit flow cross section $\left[\mathrm{kg} / \mathrm{m}^{2} / \mathrm{s}\right]$,

$d=$ channel diameter $[\mathrm{m}]$, and

$l=$ channel length $[\mathrm{m}]$. 
This correlation was developed for use in a one-g (earth gravity) environment; boiling heat transfer data for a zero-g environment representative of earth orbit is essentially nonexistent. Liquid metals typically possess very good heat transfer properties; therefore, for pin-type fuel with a gap, the thermal resistance associated with the coolant is small compared to the total core resistance and use of the one-g heat transfer coefficient correlation will not a have a significant effect on the specific power calculations. However, for cermet fuel and for pin-type fuel without a gap, the thermal resistance associated with the coolant is a large fraction of the total. For these cases, use of the one-g data is the best that can be done until zero-g data becomes available. 


\subsection{SPECIFIC POWER CALCULATIONS}

Some example specific power calculations are included in this section to demonstrate the use of the formulae presented in the previous sections.

\section{Heat Transfer Coefficient for Boiling Potassium coolant}

$$
\begin{aligned}
& \text { Assumed conditions - } \\
& \text { pressure }=1.58 \mathrm{MPa} \\
& \mathrm{l} / \mathrm{d}=260 \\
& \mathrm{~L}=1.663 \mathrm{E} 6 \mathrm{~J} / \mathrm{kg} \\
& \mathrm{x}_{1}=0.0 \\
& \mathrm{x}_{\mathrm{n}}=0.20 \\
& \mathrm{G}=1350 \mathrm{~kg} / \mathrm{s} / \mathrm{m}^{2}
\end{aligned}
$$

Calculated heat transfer coefficient:

$\mathrm{h}_{\mathrm{C}}=40,000 \mathrm{~W} / \mathrm{m}^{2} / \mathrm{K}$

\section{Specific Power for Pin-Type Fuel}

Fuel Density - $13600 \mathrm{~kg} / \mathrm{m}^{3}$

$P_{z}=P_{r}=1.0$

Dimensions:

$r_{1}=0.002213 \mathrm{~m}$

$r_{2}=0.002340 \mathrm{~m}$

$\mathrm{r}_{3}=0.002540 \mathrm{~m}$

$r_{4}=0.003175 \mathrm{~m}$

Conductivities:

fuel (Uranium Nitride) : $\mathrm{k}_{\mathrm{f}}=26.0 \mathrm{~W} / \mathrm{m} / \mathrm{K}$

liner (Tungsten): $k_{1}=110 \mathrm{~W} / \mathrm{m} / \mathrm{K}$

clad (Niobium alloy): $\mathrm{k}_{\mathrm{Cl}}=54 \mathrm{~W} / \mathrm{m} / \mathrm{K}$

Heat transfer coefficients:

gap - $5000 \mathrm{w} / \mathrm{m}^{2} / \mathrm{K}$

coolant - 40,000 $\mathrm{w} / \mathrm{m}^{2} / \mathrm{K}$

Temperatures:

Fuel centerline - $1600 \mathrm{~K}$

Coolant bulk - $1450 \mathrm{~K}$

Calculated resistances $\left(K-\mathrm{m}^{3} / \mathrm{W}\right)$ : 
$R_{\mathrm{f}}=4.71 \mathrm{E}-8$

$\mathrm{R}_{1}=1.24 \mathrm{E}-9$

$\mathrm{R}_{\mathrm{g}}=2.09 \mathrm{E}-7$

$\mathrm{R}_{\mathrm{Cl}}^{\mathrm{g}}=1.01 \mathrm{E}-8$

$R_{C}=1.93 \mathrm{E}-8$

Total $=2.87 \mathrm{E}-7$

Calculated specific power:

$P_{\mathbf{S}}=0.038 \mathrm{MW} / \mathrm{kg}$

If the maximum-allowed fuel centerline temperature is increased to $2000 \mathrm{~K}$, the specific power increases to 0.141 $\mathrm{MW} / \mathrm{kg}$. If in addition to increasing the fuel temperature the gap is eliminated, the specific power increases to $0.519 \mathrm{MW} / \mathrm{kg}$. (Elimination of the gap may be possible for reactors designed for short operation times.)

\section{Specific Power for Cermet Fuel}

Fuel Density - $13600 \mathrm{~kg} / \mathrm{m}^{3}$

$v_{f}=0.35$

$\mathrm{P}_{\mathbf{Z}}=\mathrm{P}_{\mathbf{r}}=1.0$

Dimensions:

$\mathrm{d}_{\mathrm{ch}}=0.004 \mathrm{~m}$

$\mathrm{t}_{\mathrm{par}}=0.0001 \mathrm{~m}$

Conductivities:

fuel (Uranium Nitride): $k_{f}=26.0 \mathrm{~W} / \mathrm{m} / \mathrm{K}$

matrix (Tungsten): $\mathrm{k}_{\mathrm{m}}=110 \mathrm{~W} / \mathrm{m} / \mathrm{K}$

Heat transfer coefficient:

coolant $-40,000 \mathrm{~W} / \mathrm{m}^{2} / \mathrm{K}$

Temperatures:

Fuel centerline - $1750 \mathrm{~K}$

coolant bulk - $1350 \mathrm{~K}$

Calculated resistances $\left(\mathrm{K}-\mathrm{m}^{3} / \mathrm{W}\right)$ :

$\mathrm{R}_{\text {par }}=1.6 \mathrm{E}-11$

$R_{\mathrm{m}}^{\mathrm{par}}=3.20 \mathrm{E}-9$

$R_{C}=1.51 \mathrm{E}-8$

Total $=1.83 \mathrm{E}-8$ 
Calculated specific power:

$\mathrm{P}_{\mathrm{S}}=1.606 \mathrm{MW} / \mathrm{kg}$

This calculation shows that with a cermet fuel, the resistances associated with the core are less than in the case of pin-type fuels containing a gap. Thus, for the cermet fuel, heat transfer to the coolant accounts for a large fraction of the total thermal resistance.

The example calculations are for a boiling liquid metal; however, these specific power values would be about the same for either a boiling or non-boiling liquid-metal coolant because the coolant heat transfer coefficients would be comparable.

\section{Specific Power for Thermionic Fuel}

Fuel Density - $10500 \mathrm{~kg} / \mathrm{m}^{3}$

$\mathrm{P}_{\mathrm{z}}=\mathrm{P}_{\mathrm{r}}=1.0$

Dimensions :

$r_{1}=0.00192 \mathrm{~m}$

$r_{2}^{1}=0.00525 \mathrm{~m}$

$r_{3}^{2}=0.00585 \mathrm{~m}$

Conductivity:

fuel (Uranium Dioxide): $k_{f}=2.6 \mathrm{~W} / \mathrm{m} / \mathrm{K}$

clad (Tungsten): $\mathrm{k}_{\mathrm{cl}}=110 \mathrm{w} / \mathrm{m} / \mathrm{K}$

Temperatures:

Fuel inner surface - $2900 \mathrm{~K}$

clad outer surface - $1960 \mathrm{~K}$

Calculated Resistance $\left(\mathrm{K}-\mathrm{m}^{3} / \mathrm{W}\right)$

$R_{f}=1.58 \mathrm{E}-6$

$R_{\text {cl }}=1.17 \mathrm{E}-8$

Total $=1.59 e-6$

Calculated Specific Power:

$\mathbf{P}_{\mathbf{S}}=0.056 \mathrm{MW} / \mathrm{kg}$

If the clad outer surface temperature (emitter) is increased to $2400 \mathrm{~K}$, the specific power decreases to $0.030 \mathrm{MW} / \mathrm{kg}$. 
In addition to the previous example calculations, parametric calculations were performed to determine the effect on specific power of coolant temperature and maximum-allowed fuel temperature for pin-, cermet-, and thermionic-type fuels. Also, for pin-type fuel, the effect of gap conductance was determined and for cermet fuel, the effect of the coolant heat transfer coefficient was calculated. For the thermionic fuel, the effect of fuel dimensions and emitter temperature were investigated. The results of these calculations are presented in Figures 4.1 through 4.6. These results apply for both the boiling and non-boiling cases because the coolant heat transfer coefficients are of the same order of magnitude for the two cases. Given the conceptual nature of the reactor designs and the uncertainty associated with liquid-metal boiling in a zero-g environment, the use of significantly different heat transfer coefficients is not warranted.

Figure 4.1 shows the specific power as a function of coolant temperature for pin-type fuel. The curves were generated both with and without a gap for two different maximum fuel temperatures. (A gap conductance of $5 \mathrm{~kW} / \mathrm{m}^{2} / \mathrm{K}$ was used for the with-gap cases.) The two curves for the no-gap cases show higher specific powers than the two curves for the with-gap cases because the relatively large thermal resistance associated with the gap has been eliminated. Figure 4.2 demonstrates the dependence of specific power on the gap conductance for the pin-type fuel.

Figures 4.3 and 4.4 show the specific power for the cermet fuel reactors with coolant heat transfer coefficients of 40 and $60 \mathrm{~kW} / \mathrm{m}^{2} / \mathrm{K}$, respectively. The specific power curves are presented as a function of coolant temperature and maximum fuel temperature. The cermet reactors do not have a gap; therefore, the thermal resistance associated with the coolant is a larger fraction of the total thermal resistance compared to the pin-type fuel. Increases in the coolant heat transfer coefficient are therefore more beneficial for the cermet reactors.

Figure 4.5 shows the specific power as a function of maximum-allowed fuel temperature and emitter temperature for the thermionic fuel. Increasing the emitter temperature is desirable with respect to increasing the efficiency of the thermionic process; however, higher emitter temperatures result in a decrease in the specific power. Figure 4.6 shows the specific power as a function of emitter temperature for three different fuel outer radius values. (For these calculations the void space radius, $r_{1}$, was adjusted such that $r_{1}{ }^{2} / r_{2}{ }^{2}$ was constant.) This figure shows that smaller fuel pins have a greater potential for achieving higher specific power. 


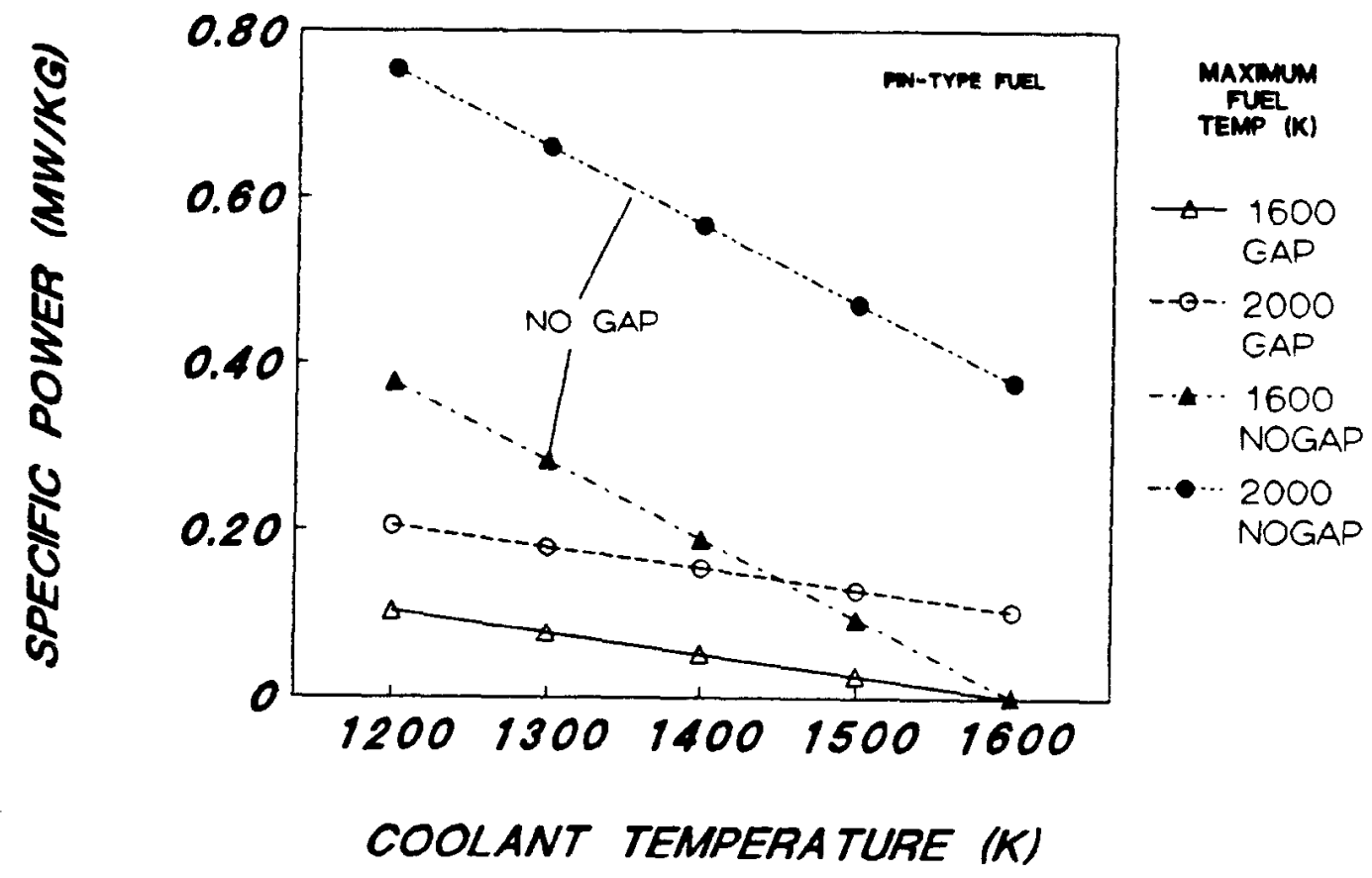

Figure 4.1 Specific Power for Pin-Type Fuel (Gap Conductance of $5 \mathrm{~kW} / \mathrm{m}^{2} / \mathrm{K}$ )

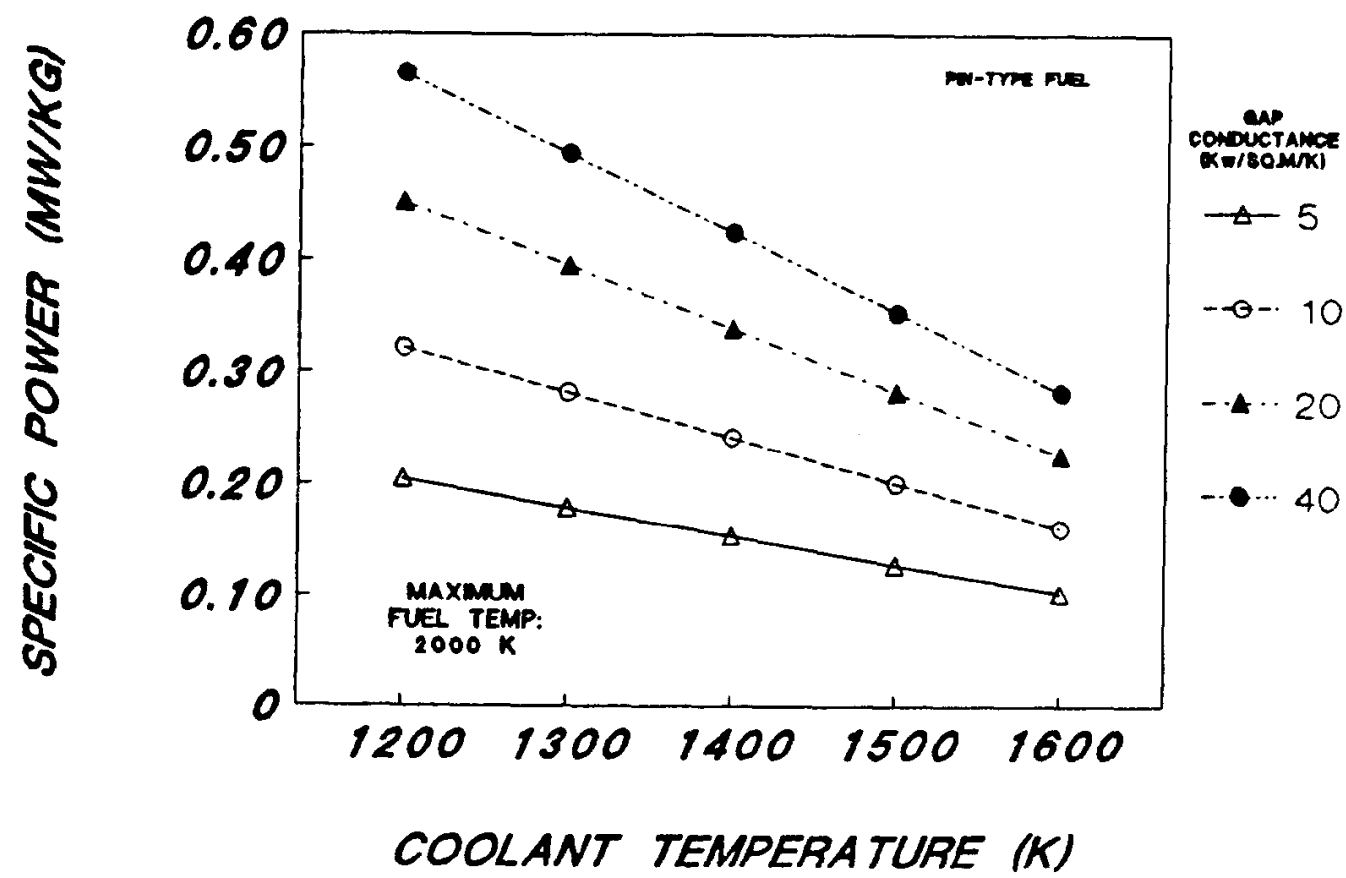

Figure 4.2 The Effect of Gap Conductance on Specific Power for Pin-Type Fuel (Maximum Fuel Temperature of $2000 \mathrm{~K}$ ) 


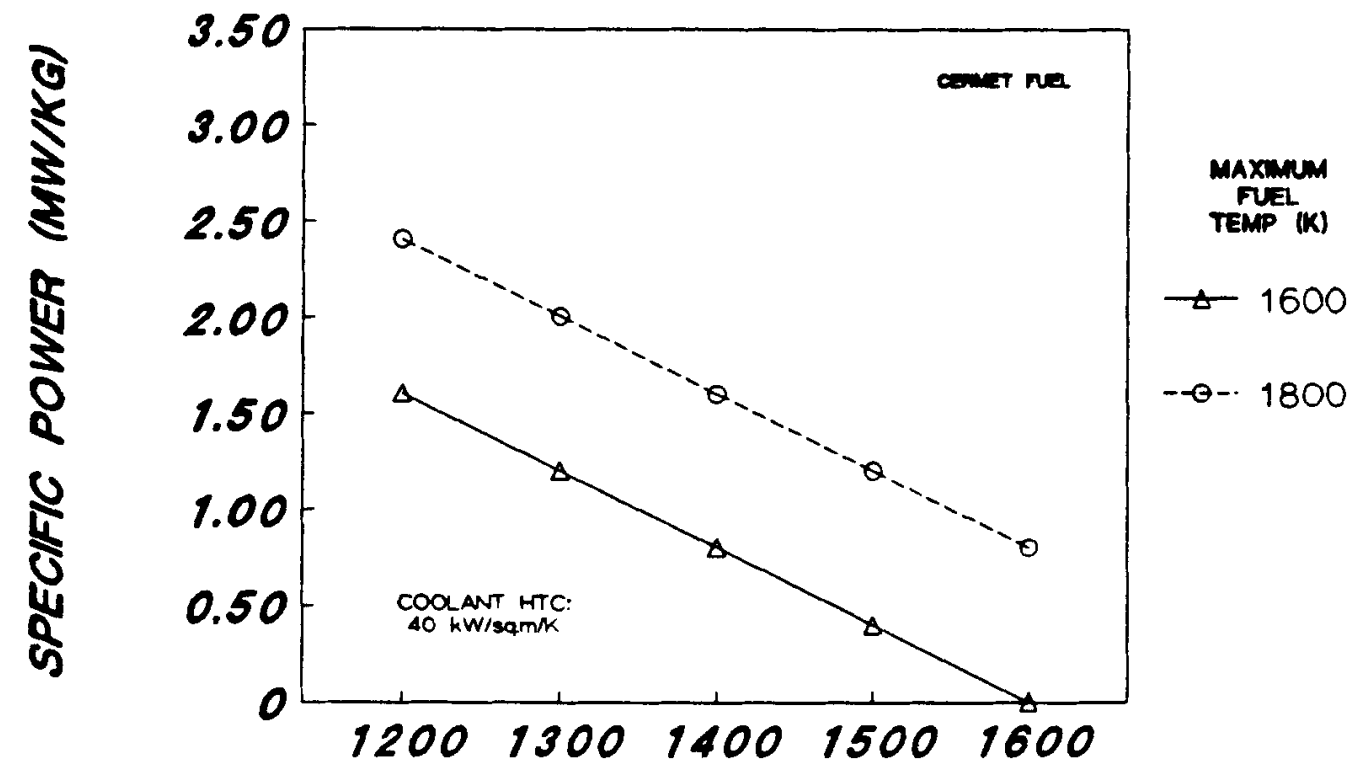

COOLANT TEMPERATURE (K)

Figure 4.3 specific Power for Cermet Fuel

(Coolant Heat Transfer Coefficient $=40 \mathrm{~kW} / \mathrm{m}^{2} / \mathrm{K}$ )

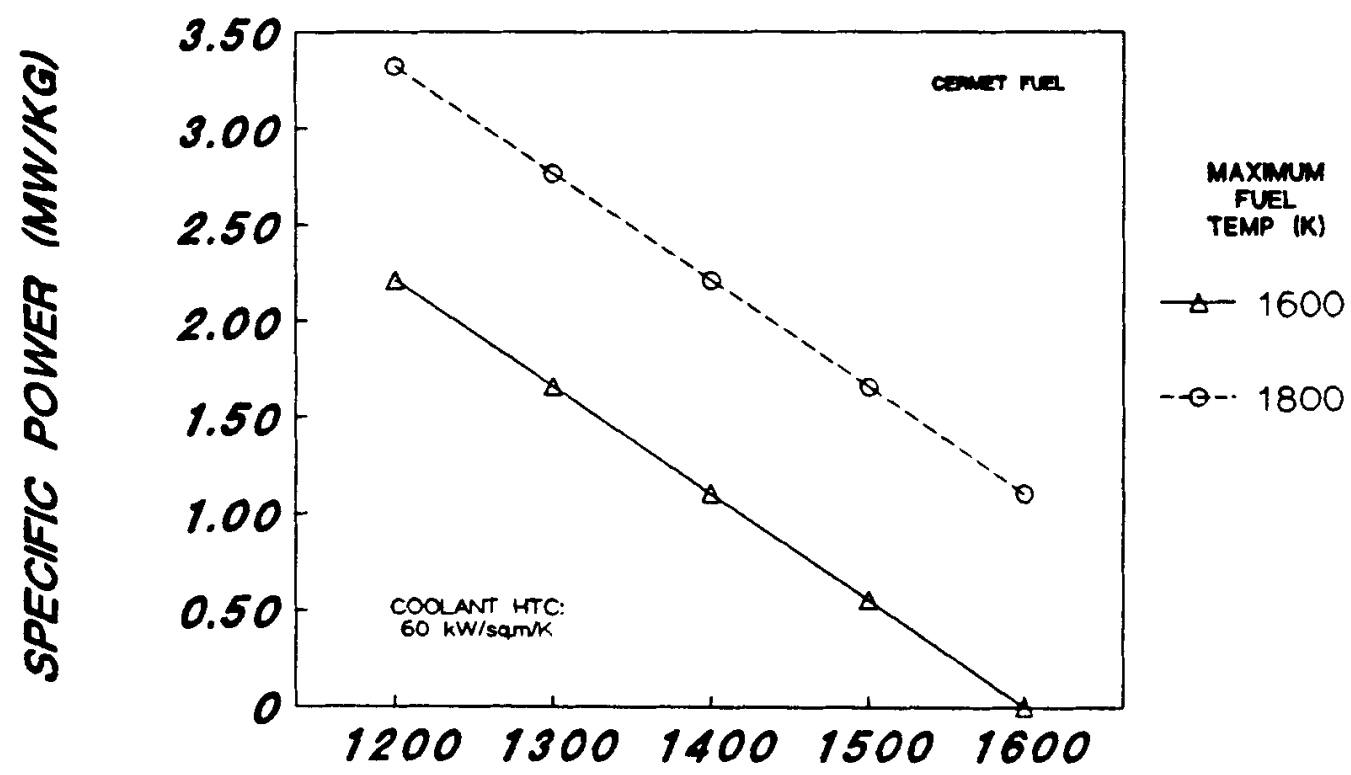

COOLANT TEMPERATURE (K)

Figure 4.4 Specific Power for cermet Fuel

(Coolant Heat Transfer Coefficient $=60 \mathrm{~kW} / \mathrm{m}^{2} / \mathrm{K}$ ) 


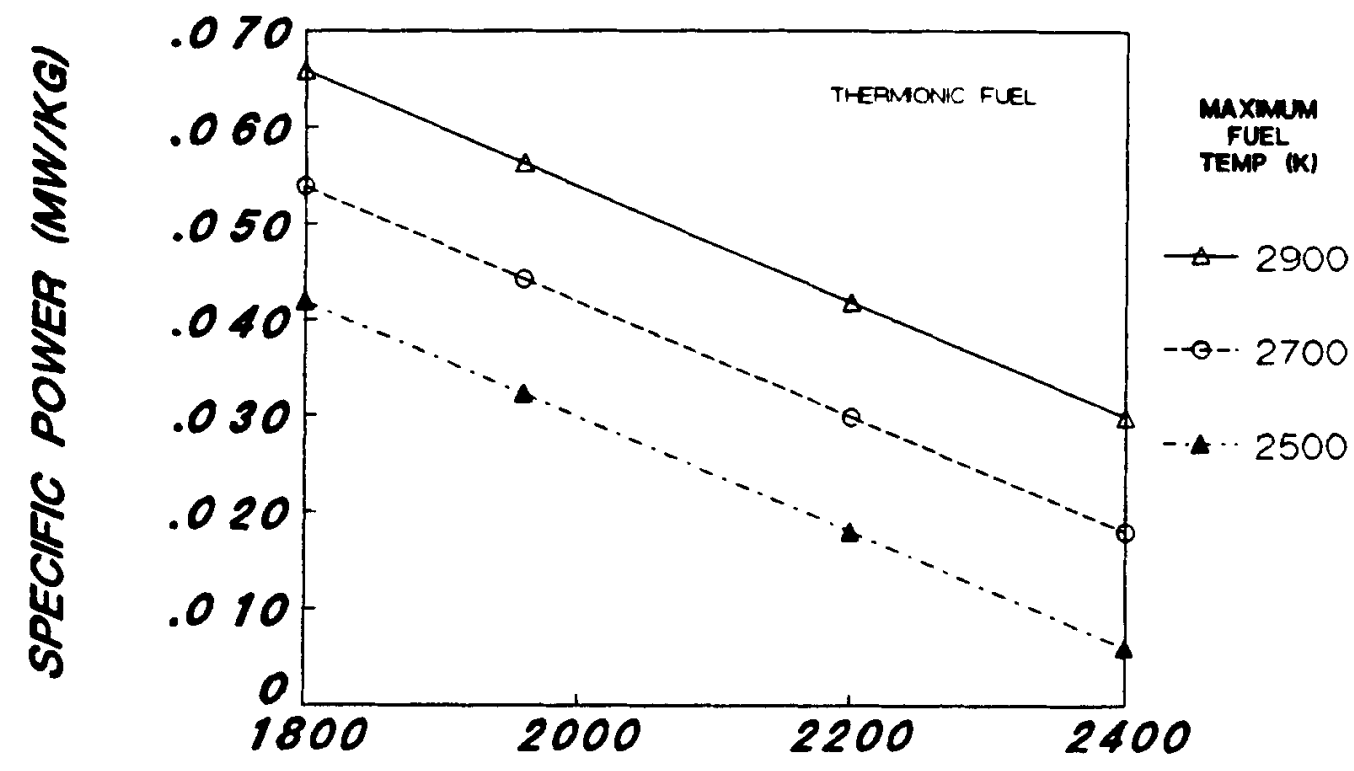

EMITTER TEMPERATURE (K)

Figure 4.5 Specific Power for Thermionic Fuel

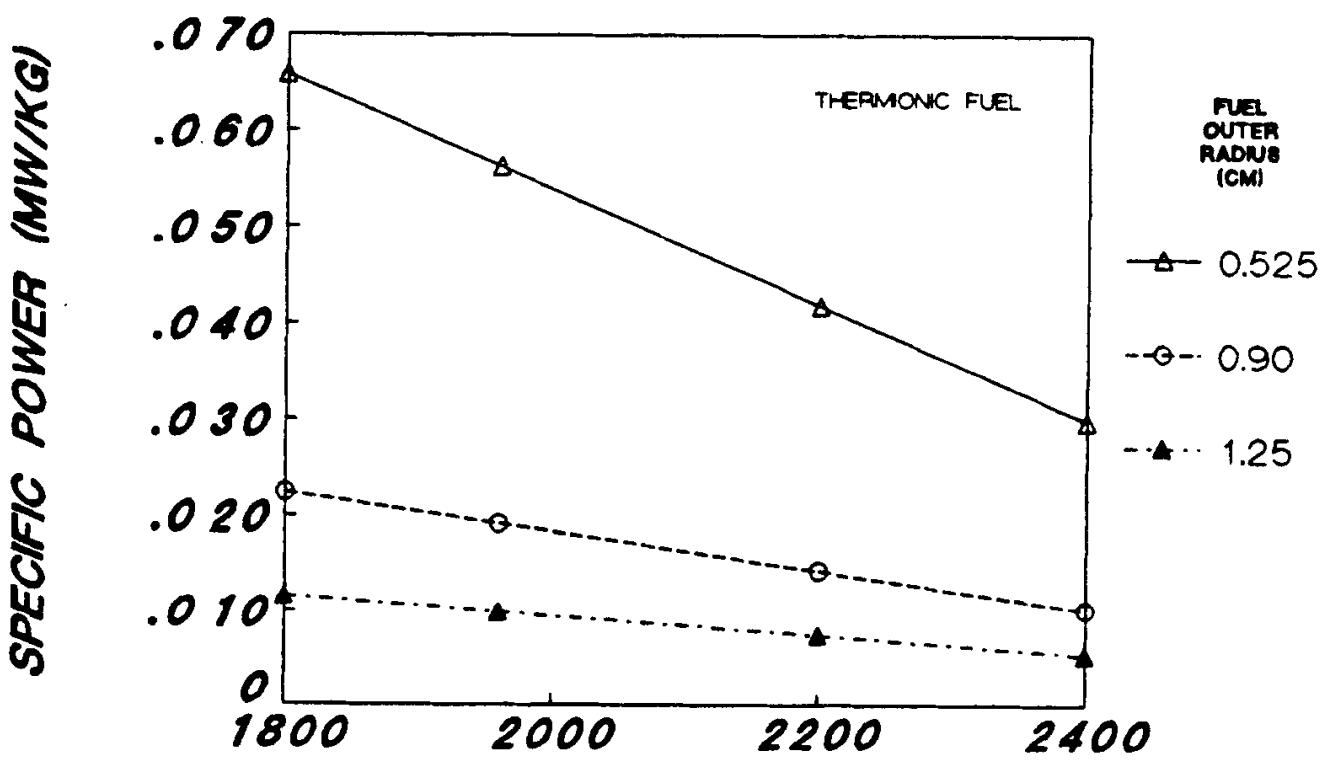

EMITTER TEMPERATURE (K)

Figure 4.6 The Effect of Fuel Dimensions on the Specific Power of Thermionic Fuel (Maximum Fuel Temperature of $2900 \mathrm{~K}$ ) 


\section{0 CRITICAL HEAT FLUX CONCERNS}

A problem that arises with boiling liquid-metal-cooled reactors is the determination of the critical heat flux, especially in a zero-g environment. The maximum heat flux occurring at any location in the core can not exceed the critical heat flux if dryout is to be avoided. Dryout would lead to possible fuel or cladding damage. Boiling water reactors typically operate such that the maximum heat flux is a factor of about two below the critical heat flux to provide a margin of safety during normal operation. For space-based liquid-metalcooled reactors, it is possible that the requirement to maintain the maximum heat flux below the critical heat flux will limit the specific power.

A correlation for critical heat flux [7] in a one-g environment with liquid metals at pressures below 2 bars is given by:

$$
q_{c}^{\prime \prime}=0.216 L\left(1-2 x_{1}\right) G^{0.807}(d / 1)^{0.807}
$$

where; $q_{c} "=$ critical heat $f l u x\left[w / m^{2}\right]$.

Critical heat flux correlations for liquid metals in a zero-g environment do not exist. Even the available data for two-phase heat transfer in zero-g for common fluids such as water is very limited. However, the available evidence seems to indicate that the critical heat flux will be lower in a reduced gravity environment than in a one-g environment. Figure 5.1 [8] shows the critical heat flux at reduced gravity divided by the critical heat flux at earth gravity for several fluids. Figure 5.2 [8] shows the boiling curve for several fluids at one-g and at reduced $\mathrm{g}$. These figures indicate that the zero-g critical heat flux is reduced by roughly a factor of three. It must be noted that both Figures 5.1 and 5.2 are based on pool boiling experiments. The effects on forced-flow critical heat flux at reduced gravity are really not known. However, there is some evidence to indicate that for high flow rates, the reduction in critical heat flux associated with reduced gravity will be less for forced convection boiling than for pool boiling. It is not clear how great the flow rate must be to suppress the possible detrimental effects associated with reduced gravity.

The peak heat flux for a reactor core can be expressed as:

$$
q_{p}{ }^{\prime \prime}=P_{z} P_{r} 0.25(G d / l)\left[C_{p}\left(T_{s a t}-T_{i}\right)+x_{n} L\right]
$$

where: $q_{p}^{\prime \prime}=$ peak heat flux,

$\mathrm{c}_{\mathrm{p}}^{\mathrm{p}}=$ specific heat,

$T_{\text {sat }}^{\text {p }}$ saturation temperature, and

$T_{i}=$ core inlet temperature.

The first term in the brackets accounts for sensible heat addition and the second term accounts for latent heat addition. 
The peak heat flux expression can be combined with the expression for critical heat flux to yield:

$$
q_{c}{ }^{\prime \prime} / q_{p} "=0.864 L\left(1-2 x_{1}\right) Y /\left[P_{z} P_{r}\left(c_{p} \Delta T+x_{n} L\right)\right]
$$

with; $Y=(1 / d / G) 0.193$

and $\Delta T=T_{\text {sat }}-T_{i}$.

If this ratio is below some acceptable design limit, the specific power would have to be reduced accordingly. An example critical heat flux calculation is presented below for potassium coolant in a one-g environment.

\section{Calculation of Critical Heat Flux Ratio}

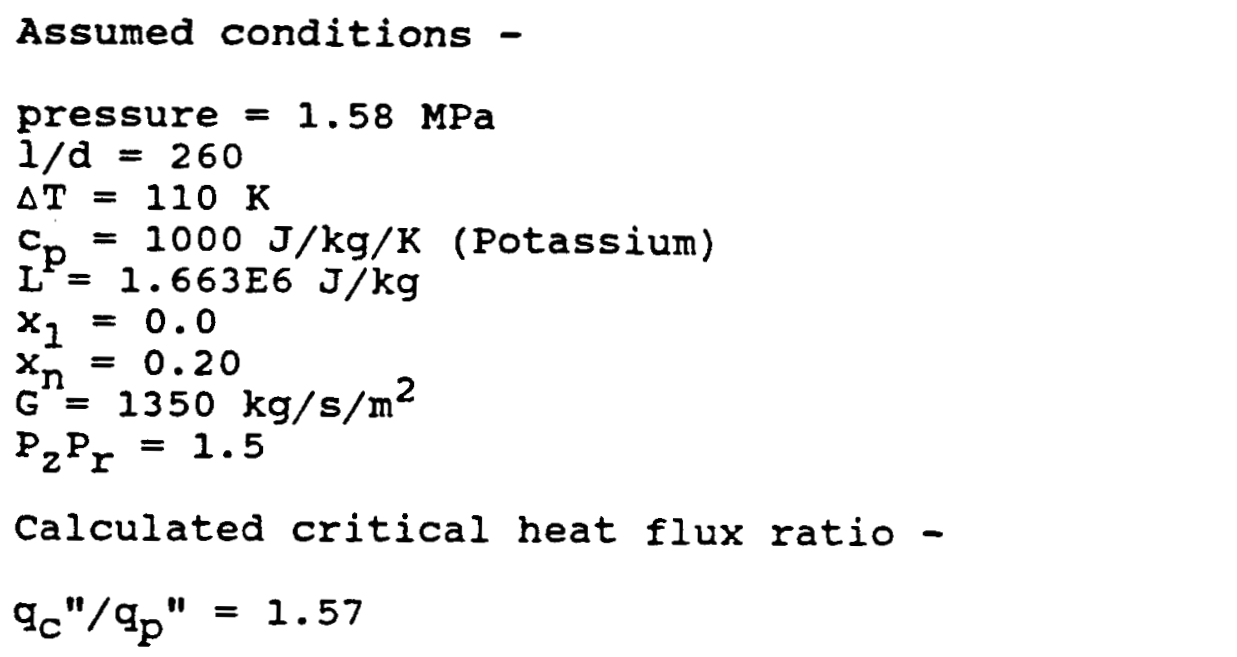

The uncertainty associated with this result is substantial given the very limited amount of test data that is available for critical heat flux along with the fact that the reactor parameters are based on a conceptual design. Also, recall that the correlation for critical heat flux was based on results for pressures below 2 bars. This result however, gives an indication that the critical heat flux constraint associated with a boiling liquid metal may be a problem, especially if the effects of zero-g prove to be detrimental. 


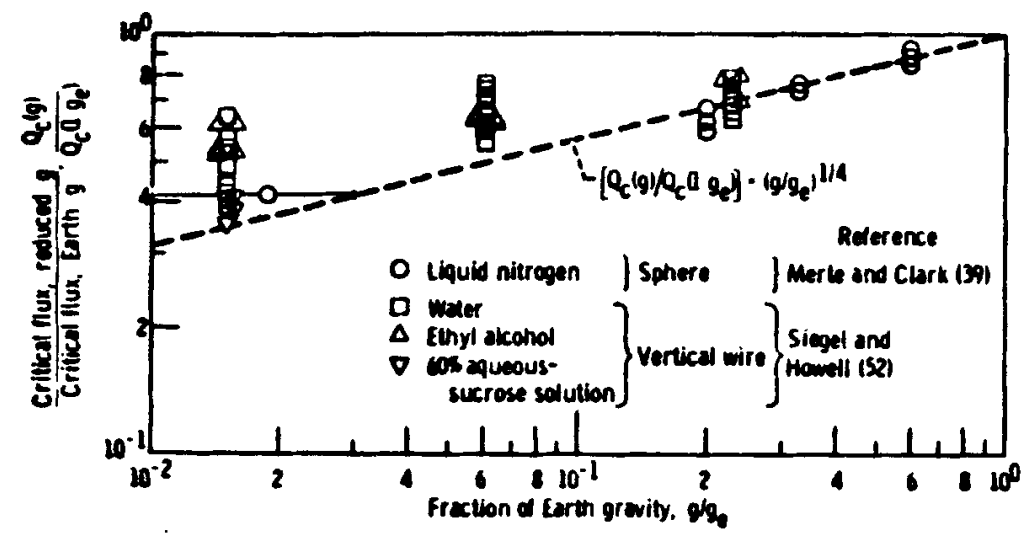

Figure 5.1 Effects of Reduced Gravity on Critical Heat Flux [8]

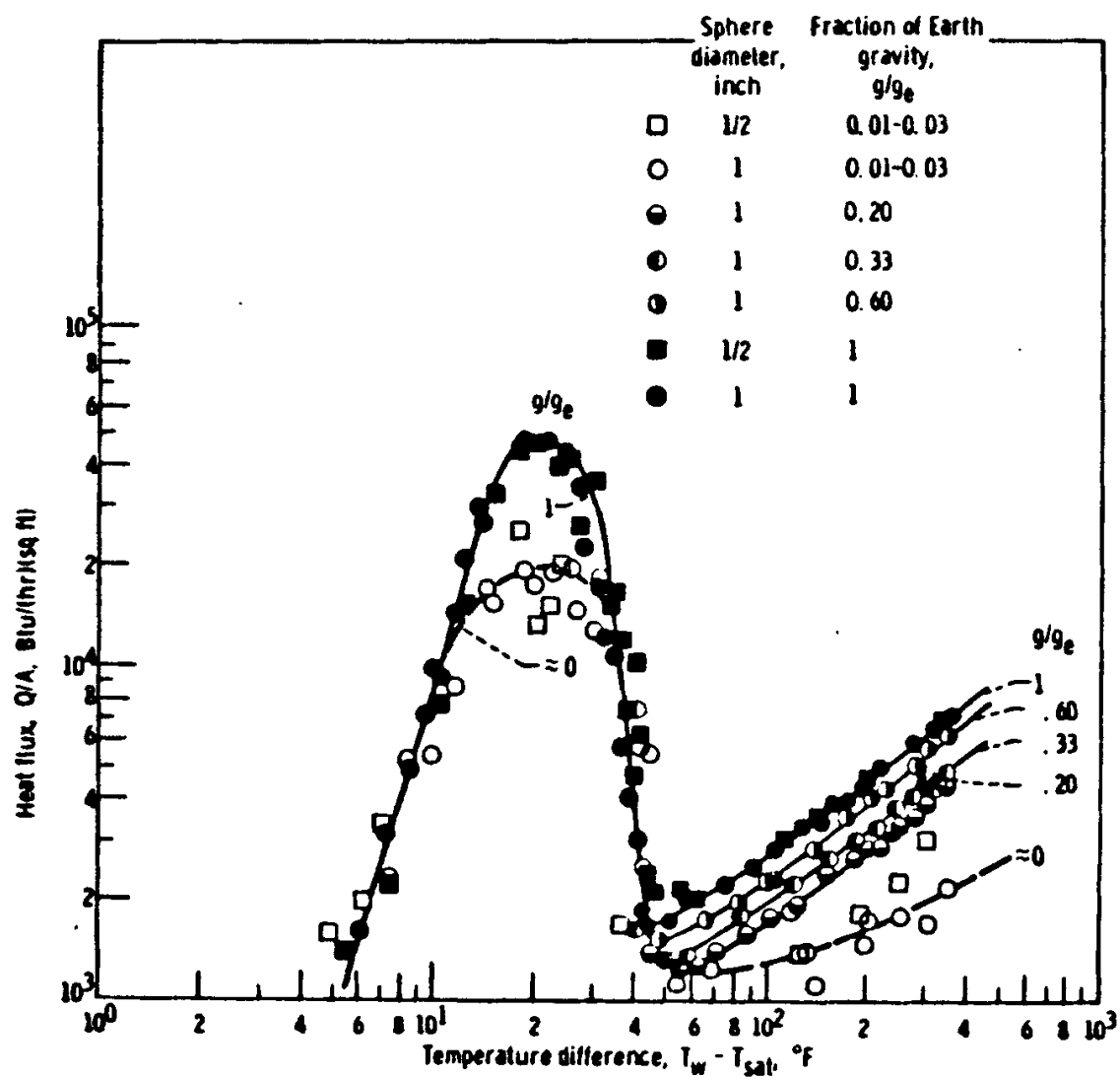

Figure 5.2 Boiling Curve at Reduced Gravity [8] 


\subsection{LOSS-OF-COOLANT CONCERNS}

As discussed in the previous section, it might be necessary to restrict the specific power because of critical heat flux concerns. Another concern is that of core temperature response during an accident situation such as a loss-of-coolant accident. In space, one does not have the luxury of being able to collect core coolant in a sump for subsequent recirculation through the core. Once the coolant is lost, there is no easy way of providing core cooling. The only cooling mechanism readily available is by way of radiant heat transfer from the vessel to space. Prevention of fission product release dictates that the vessel remain intact; prevention of fuel melting may not be necessary but certainly would also be desirable. Thus, such safety-related concerns must be considered when determining the core specific power.

Although reactors with high specific powers enjoy the benefit of reduced weight and volume, these benefits become detriments with respect to the core's temperature response following a loss-of-coolant accident. Reduced weight results in a reduction in core heat capacity while reduced volume results in a reduction in available surface area for radiation to space. It may be necessary to reduce a core's specific power to avoid these detrimental effects.

To address this concern, a very simple loss-of-coolant accident analysis was performed for the pin-type and cermet reactors described in section 2. A detailed analysis would require a very detailed description of the reactors and is far beyond the scope of this work. The intent of this simple analysis is to demonstrate the relative temperature response of the two types of liquid-metal-cooled reactors and thus point out possible safety-related concerns and how those concerns may effect the specific power. (Some preliminary loss-of-coolant accident analyses for low-power space reactors are presented in [10]. The work described in that reference attempts to model the effects during postulated accidents of some of the specific design details of several proposed space reactors.)

To make this otherwise difficult problem tractable, numerous assumptions and simplifications were necessary. First, it was assumed that the core is not surrounded by a vessel or any other structure and that the outer radial surface of the cylindrically shaped core radiates directly to space. Inclusion of the vessel or any other structure between the core and space (such as a neutron reflector or multifoil insulation) would introduce additional thermal resistance making heat rejection to space much more difficult and resulting in higher core temperatures. (Reference 10 provides an indication of the magnitude of these effects.) 
The effective temperature of space was selected as $250 \mathrm{~K}$ and the emissivity of the outer core surface was chosen as 0.3 . All coolant was assumed to be lost instantaneously at the start of the accident. Reactor SCRAM was also assumed to occur at the start of the accident. The ANS standard decay power function with infinite irradiation time was used to calculate the core decay power after SCRAM. Although this function was not intended for fast spectrum liquid-metal-cooled reactors, it provides a reasonable estimate of decay power for this analysis. A further assumption that was necessary for the pin-type fuel was the selection of a suitable view factor to space. Because the pins near the core center do not have a clear view of space, their view factor is essentially zero. Pins at the core periphery have a view factor of approximately 0.5 (half of their surfaces directly view space). An "effective" view factor representative of all the fuel pins was arbitrarily selected as 0.15 . Again, a more detailed model would be required to accurately model this complex situation and is beyond the intent of this analysis.

The transient temperature response of the core was calculated using a lumped-parameter approach [9]. In this approach, the thermal capacitance of all of the core materials are "lumped" together to provide a single effective computational node. The differential equation describing the transient temperature response of this single node is:

$$
\left(\rho c_{\mathrm{p}} \mathrm{V}\right) \mathrm{dT} / \mathrm{dt}=\mathrm{P}-\sigma \mathrm{A}\left(\mathrm{T}^{4}-\mathrm{T}_{\mathbf{s}}{ }^{4}\right) /(1 / \epsilon+1 / \mathrm{F}-1)
$$

where; $\rho=$ node volume-averaged density,

$$
\begin{aligned}
& C_{p}=\text { node mass-averaged specific heat, } \\
& V^{p}=\text { node volume, } \\
& T=\text { node temperature, } \\
& t=\text { time, } \\
& P=\text { time-dependant core decay power, } \\
& \sigma=\text { stefan-Boltzmann constant, } \\
& \epsilon=\text { radiating-surface emissivity, } \\
& F=\text { view factor, } \\
& A=\text { radiating-surface area, and } \\
& T_{S}=\text { effective space temperature }=250 \mathrm{~K} \text {. }
\end{aligned}
$$

This differential equation was solved using Euler's method [11]. The node properties for the pin-type and cermet cores, based on the information presented in section 4 , are provided in Table 6.1.

Table 6.1

Pin-Type and Cermet core Node Properties

$\begin{array}{lcr} & \text { Pin-Type } & \text { cermet } \\ \text { Density }\left(\mathrm{kg} / \mathrm{m}^{3}\right) & 5912 & 12114 \\ \text { Specific Heat }(\mathrm{J} / \mathrm{kg} / \mathrm{K}): & 260 & 168\end{array}$


The node volume, $v$, was determined based on the core specific powers. First, the specific power was converted to a core power density, $P_{d}$, using the following:

$$
P_{\mathrm{d}}=\mathrm{P}_{\mathrm{s}} \rho \mathrm{V}_{\mathrm{f}}\left(1-\mathrm{V}_{\mathrm{c}}\right)
$$

where; $V_{f}=$ fuel volume fraction,

$v_{C}=$ core void fraction, and

$\rho=$ fuel density.

For the pin-type fuel, the fuel volume fraction is the fraction of the fuel rod volume occupied by fuel (UN). For the cermet fuel, it is the fraction of the solid core material volume (W and UN) occupied by fuel. The core void fraction is the fraction of the core volume normally occupied by coolant.

Using the calculated power density, the total volume of the core, $V$, was calculated as $P / P_{d}$. Assuming a cylindrical core with a height-to-diameter ratio of 1.0 , the core diameter, $D$, was calculated as:

$$
D=(4 \mathrm{~V} / \mathrm{II})^{1 / 3}
$$

A summary of the pertinent core parameters is provided in Table 6.2 for the pin-type and cermet cores. A steady-state core power of $50 \mathrm{MW}$ was assumed for both cores.

$$
\text { Table } 6.2
$$

Core Parameters

$\begin{array}{lrr} & \text { Pin-Type } & \text { Cermet } \\ \mathrm{P}_{\mathrm{s}}(\mathrm{MW} / \mathrm{kg}): & 0.038 & 1.606 \\ \mathrm{~V}_{\mathrm{f}}: & 0.485 & 0.35 \\ \mathrm{~V}_{\mathrm{C}}:\left(\mathrm{MW} / \mathrm{m}^{3}\right): & 0.45 & 0.30 \\ \mathrm{P}_{\mathrm{d}}\left(\mathrm{m}^{3}\right): & 137.8 & 5351.1 \\ \mathrm{~V}_{\mathrm{D}}(\mathrm{m}): & 0.3625 & 0.0093 \\ \mathrm{~N} & 0.7728 & 0.2283\end{array}$

The calculated temperature responses for both cores are shown in Figure 6.1. Two curves are shown for the cermet core, the second curve shows the core temperature response if the power density is reduced by a factor of ten from its original value. The temperature for the pin-type core peaks at a value of $3040 \mathrm{~K}$ at about 22 minutes. At this time, the rate of decay power generation in the core is equal to the rate at which power is removed from the core by radiation to space. The core temperature then slowly decreases as the power continues to 
decay. At approximately one minute, the cermet core temperature peaks at $5164 \mathrm{~K}$ which is over $2000 \mathrm{~K}$ higher than the pin-type core peak temperature.

If it is assumed that the peak core temperature must remain below $3000 \mathrm{~K}$ (the approximate melting temperature of UN), then clearly the specific power of the cermet core must be reduced. Reducing the specific power by a factor of ten reduces the peak temperature by $1964 \mathrm{~K}$ to a value of $3200 \mathrm{~K}$. (This peak. temperature occurs at about six minutes.) Thus, much of the benefit offered by cermet fuel, with respect to specific power, may be lost after safety-related concerns are addressed. A better assessment of the possible specific power penalty can be made only after complete designs of the reactors are available; it is expected that the transient temperature response will be strongly dependent on the details of the design. A more sophisticated analysis will be warranted when the design details are available. 


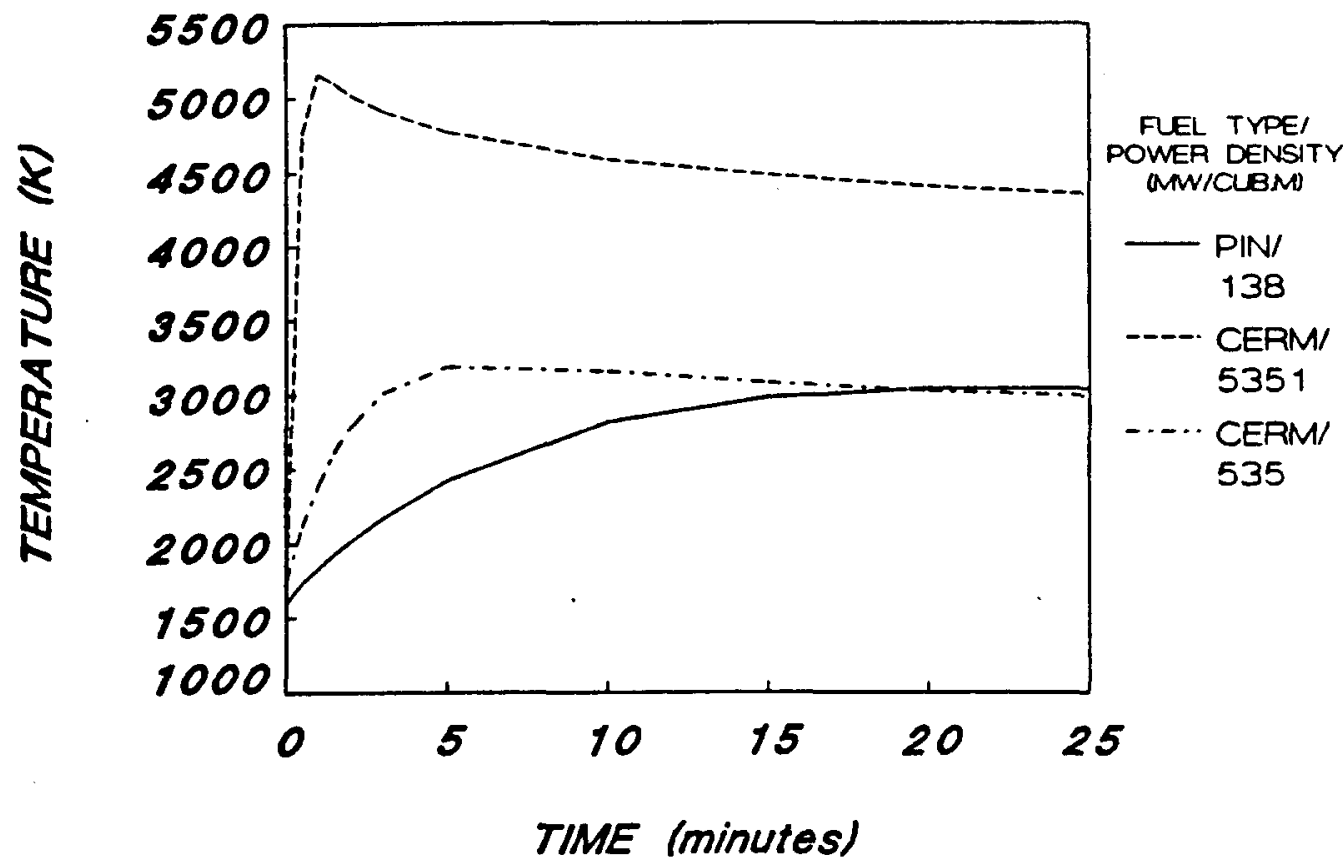

Figure 6.1 Core Temperature Response Following a Loss-of-Coolant Accident (Pin-Type and Cermet Cores) 


\subsection{SUMMARY}

The specific power for space-based liquid-metal-cooled reactors was determined for three different fuel types: (1) pin-type fuel, (2) cermet fuel, and (3) thermionic fuel.

The specific power for the pin-type fuel ranged between about 0.04 and $0.6 \mathrm{MW} / \mathrm{kg}$ depending on the maximum-allowed fuel temperature, coolant temperature, and gap conductance. High maximum-allowed fuel temperature, low coolant temperature, and high gap conductance were most favorable with respect to specific power. Liquid metals possess good heat transfer properties, therefore, the thermal resistance associated with the coolant was relatively small. Because the thermal resistance associated with the gap dominated the total resistance, elimination of the gap resulted in significant increases in the specific power.

The specific power for the cermet fuels varied between about 1.0 and $3.5 \mathrm{MW} / \mathrm{kg}$, again depending on the fuel and coolant temperatures. Because the cermet fuels do not have a gap and because the matrix material possesses very good thermal conductivity, the thermal resistance associated with the coolant was relatively large. Therefore, increasing the coolant heat transfer coefficient was most beneficial for the cermet fuels.

The specific power for the thermionic fuels ranged between 0.01 and $0.07 \mathrm{MW} / \mathrm{kg}$ depending on maximum-allowed fuel temperature, emitter temperature, and pin diameter. High emitter temperatures are not advantageous with respect to specific power for thermionic fuel. Large diameter pins have lower specific powers compared to the small diameter pins.

Critical heat flux data for liquid metals in a zero-g environment is essentially nonexistent. However, based on data for other fluids, it appears that critical heat flux concerns may limit the specific power for space-based liquid-metal-cooled reactors.

Another concern that may limit the specific power is the fuel temperature response following a loss-of-coolant accident. Very simplistic calculations indicated that it may be necessary to significantly reduce the core specific power in order to prevent fuel melting following such an accident. such safetyrelated concerns should be considered in the design of a space-based reactor. 


\subsection{REFERENCES}

1. Albert C. Marshall, "RSMAss: A Preliminary Reactor/Shield Mass Model for SDI Applications," SAND86-1020, August 1986.

2. Albert C. Marshall, "A Review of Gas-Cooled Reactor Concepts for SDI Applications," INF-6511-8702, Feb. 1987.

3. Dean Dobranich, "A Computer Program To Determine the Specific Power of Prismatic-Core Reactors," SAND87-0735, May 1987.

4. Y. S. Tang, R. D. Coffield, Jr., R. A. Markley, THERMAL ANALYSIS OF LIQUID METAL FAST BREEDER REACTORS, American Nuclear Society, 1978.

5. M. M. El-Wakil, NUCLEAR POWER ENGINEERING, MCGraw-Hill, 1962 .

6. O. E. DWYer, BOILING LIQUID-METAL HEAT TRANSFER, American Nuclear Society, 1976.

7. H. M. Kottowski and C. Savatteri, "Fundamentals of Liquid Metal Boiling Thermohydraulics," Nuclear Engineering and Design, Vol. 82, 1984, pp. 281-304.

8. Robert Siegel, "Effects of Reduced Gravity on Heat Transfer," Advances in Heat Transfer, Vol. 4, 1967.

9. Frank Kreith, PRINCIPLES OF HEAT TRANSFER, Third Edition, Intext Educational Publishers, 1976.

10. L. N. Kmetyk, J. H. Lee, S. W. Webb, R. M. Summers and J. C. Cleveland, "Preliminary Design Considerations for Safe, on-orbit operations of Space Nuclear Reactors, " SAND87-0865, (to be published).

11. Conte and de Boor, ELEMENTARY NUMERICAL ANALYSIS, McGraw-Hill, 1972 . 
DISTRIBUTION

AFAT/SAS

Fort Walton Beach, FL 32542

Attn: Capt. Jerry Brown

AFISC/SNAR

Kirtland Air Force Base

New Mexico 87117

Attn: Lt. Col. J. P. Joyce

AF Astronautics Laboratory/LKCJ

Edwards Air Force Base

MS 24

California 93523

Attn: G. Beale

AF Astronautics Laboratory/LKCJ

Edwards Air Force Base

California 93523

Attn: F. Meade

AF Astronautics Laboratory/LKCJ Edwards Air Force Base

California 93523

Attn: Lt. R. Henley

AF Astronautics Laboratory/LKCJ

Edwards Air Force Base

California 93523

Attn: Major E. Houston

AFWAL/AA

Wright-Patterson AFB

Ohio 45433

Attn: Dick Renski

AFWAL/POOS

Wright-Patterson AFB

Bldg. 450

Ohio 45433

Attn: E. B. Kennel

AFWAL/POOC-1

Bldg. 450

Wright-Patterson AF Base

Ohio 45433

Attn: R. Thibodeau
AFWAL/POO

Aeronautical Laboratory

Wright-Patterson AFB

Ohio 45433

Attn: $\mathbf{w}$. Borger

Aeronautical Laboratory

Bldg. 18

Wright-Patterson AFB

Ohio 45433

Attn: P. Colgrove

AFWAL/POOC-1

Aeronautical Laboratory

Bldg. 450

Wright-Patterson AFB

Ohio 45433

Attn: D. Massie

AFWAL/POOC-1

Aeronautical Laboratory

Wright-Patterson AFB

Ohio 45433

Attn: c. Oberly

AFWAL/POOC-1

Aeronautical Laboratory Wright-Patterson AFB

Ohio 45433

Attn: T. Mahefky

AFWAL/POOS

Wright-Patterson AFB

Ohio 45433

Attn: J. Beam

AFWAL/POOC-1

Power Components Branch

Wright Patterson AFB

Ohio 45433-6563

AFWAL/POOC

Aeronautical Laboratory Bldg. 18

Wright-Patterson AFB

Ohio 45433

Attn: Major seward 
AFWL/AFSC

Kirtland Air Force Base

New Mexico 87117

Attn: M. J. Schuller

\section{AFWL/AW}

Kirtland AFB

New Mexico 87117

Attn: Dr. D. Kelleher

Kirtland Air Force Base

New Mexico 87117

Attn: Lt. Col. Jackson

AFWL/AWYS

Kirtland Air Force Base

New Mexico 87117

Attn: Major D. R. Boyle

HQ AFSPACECOM/XPXIS

Peterson Air Force Base

Colorado 80914-5001

Attn: Lt. Col. F. Lawrence

HQ USAF/RD-D

Washington, DC 20330-5042

Attn: Maj. P. Talty

Aerospace Corporation

Bldg. 497, Rm. 123

P. O. Box 9113

Albuquerque, NM 87119

Attn: $\quad$. Zelinski

Aerospace Corporation

P. O. Box 9113

Albuquerque, NM 87119

Attn: W. Blocker

Aerospace Corporation

P. O. Box 9113

Albuquerque, NM 87119

Attn: M. Firmin

Aerospace Corporation

P. O. Box 92957

El Segundo, CA 90009

Attn: P. Margolis
Air Force Center for studies
and Analyses/SASD

The Pentagon, Room ID-431

washington, DC 20330-5420

Attn: w. Barattino, AFCSA/SASD

Air Force Foreign Technology Div. TQTD

Wright-Patterson AFB

Ohio 45433-6563

Attn: Dr. B. L. Ballard

TQTD

Wright-Patterson AFB

Ohio 45433-6563

Attn: K. W. Hoffman

Air Force Space Technology center SWL

Kirtland AFB, NM 87117-6008

Attn: Capt. M. Brasher

Air Force Space Technology center SWL

Kirtland AFB, NM 87117-6008

Attn: J. DiTucci

Air Force Space Technology Center SWL

Kirtland AFB, NM 87117-6008

Attn: Capt. E. Fornoles

Air Force Space Technology Center TP

Kirtland AFB, NM 87117-6008

Attn: M. Good

Air Force Space Technology Center XLP

Kirtland AFB, NM 87117-6008

Attn: A. Huber

Air Force Space Technology Center SWL

Kirtland AFB, NM 87117-6008

Attn: Capt. S. Peterson 
ANSER Corp.

Crystal Gateway 3

1225 Jefferson Davis Highway \#800

Arlington, VA 22208

Attn: K. C. Hartkay

Argonne National Laboratory

9700 S. Cass Avenue

Argonne, IL 60439

Attn: Dr. Samit K. Bhattacharyya

Argonne National Laboratory

9700 S. Cass Avenue

Argonne, IL 60439

Attn: D. C. Fee

9700 S. Cass Avenue

Argonne, IL 60439

Attn: K. D. Kuczen

Argonne National Laboratory

9700 S. Cass Avenue

Argonne, IL 60439

Attn: Dr. R. A. Lewis

Argonne National Laboratory

9700 S. Cass Avenue

Argonne, IL 60439

Attn: D. C. Wade

Auburn University

202 Sanform Hall

Auburn, AL 36849-3501

Attn: Dr. T. Hyder

Auburn University

231 Leach Center

Auburn, AL 36849-3501

Attn: Dr. F. Rose

Avco Research Laboratory

2385 Revere Beach Pkwy

Everett, Mass. 02149

Attn: D. W. Swallom
Babcock \& Wilcox

Nuclear Power Division

3315 Old Forest Road

P.O. Box 10935

Lynchburg, VA 24506-0935

Attn: B. J. Short

Battelle Pacific Northwest Lab. P. O. Box 999

Richland, WA 99352

Attn: J. O. Barner

Battelle Pacific Northwest Lab. P. O. Box 999

Richland, WA 99352

Attn: Dr. L. Schmid

Battelle Pacific Northwest Lab. P. O. Box 999

Richland, WA 99352

Attn: E. P. Coomes

Battelle Pacific Northwest Lab. P.O. Box 999

Richland, WA 99352

Attn: B. M. Johnson

Battelle Pacific Northwest Lab. P. O. Box 999

Richland, WA 99352

Attn: W. J. Krotiuk

Battelle Pacific Northwest Lab. P. O. Box 999

Richland, WA 99352

Attn: W. J. Widrig

Boeing Company

P.O. Box 3999

MS $8 \mathrm{~K}-30$

Seattle, WA 98124-2499

Attn: Dr. A. Sutey

Boeing Company

Boeing Aerospace system

P.O. BoX 3707

Seattle, WA 98124

Attn: K. Kennerud 
Brookhaven National Laboratory P.O. Box 155

Upton, NY 11973

Attn: T. Bowden

Brookhaven National Laboratory P.O. Box 155

Upton, NY 11973

Attn: H. Ludewig

Brookhaven National Laboratory P.O. Box 155

Upton, NY 11973

Attn: Dr. W. Y. Kato

Brookhaven National Laboratory Bldg. 701, Level 143

MS $820 \mathrm{M}$

P.O. BoX 155

Upton, NY 11973

Attn: Dr. J. Powell

California Inst. of Technology Jet Propulsion Laboratory 4800 Oak Grove Drive Pasadena, CA 91109

Attn: v. C. Truscello

Jet Propulsion Laboratory

4800 Oak Grove Drive

MS 122-123

Pasadena, CA 91109

Attn: P. Bankston

California Inst. of Technology Jet Propulsion Laboratory

MS 502-307

4800 Oak Grove Drive

Pasadena, CA 91109

Attn: E. P. Framan

California Inst. of Technology

Jet Propulsion Laboratory

MS 264-770

4800 Oak Grove Drive

Pasadena, CA 91109

Attn: L. Isenberg
California Inst. of Technology

Jet Propulsion Laboratory

4800 Oak Grove Drive

Pasadena, CA 91109

Attn: $J$. Mondt

DARPA

1400 Wilson Blvd.

Arlington, VA 22209

Attn: P. Kemmey

DCsCoN Consulting

4265 Drake Court

Livermore, CA 94550

Attn: D. C. Sewell

Defense Nuclear Agency

6801 Telegraph Road

Alexandria, VA 22310-3398

Attn: J. Farber/RAEV

DNA/RAEV

6801 Telegraph Road

Alexandria, VA 22310-3398

Attn: J. Foster

EG\&G Idaho, Inc./INEL

P.O. Box 1625

Idaho Falls, ID 83415

Attn: R. Rice

EG\&G Idaho, Inc./INEL

P.O. Box 1625

Idaho Falls, ID 83415

Attn: J. Dearien

EG\&G Idaho, Inc./INEL

P.O. Box 1625

Idaho Falls, ID 83415

Attn: M. L. Stanley

EG\&G Idaho, Inc./INEL

P.O. Box 1625

Idaho Falls, ID 83415

Attn: R. D. Struthers 
EG\&G Idaho, Inc./INEL P.O. BoX 1625

Idaho Falls, ID 83415

Attn: J. F. Whitbeck

EG\&G Idaho, Inc./INEL

P.O. Box 1625

Idaho Falls, ID 83415

Attn: P. W. Dickson

EG\&G Idaho, Inc./INEL

P.O. Box 1625

Idaho Falls, ID 83415

Attn: J. W. Henscheid

Ford Aerospace Corporation

Aeronutronic Div.

Ford Road, P.O. Box A

Newport Beach, CA 92658-9983

Attn: V. Pizzuro

GA Technologies

P.O. Box 85608

San Diego, CA 92138

Attn: H. J. Snyder

GA Technologies

P.O. Box 85608

San Diego, CA 92138

Attn: C. Fisher

GA Technologies

P.O. Box 85608

San Diego, CA 92138

Attn: Dr. R. Dahlberg

Garrett Fluid Systems Co. P.O. Box 5217 .

Phoenix, AZ 85010

Attn: Robert Boyle

General Electric

P. O. Box 8555

Astro Systems

Philadelphia, PA 19101

Attn: Dr. R. J. Katucki
General Electric NSTO 310 DeGuigne Drive Sunnyvale, CA 90486 Attn: E. E. Gerrels

General Electric NSTO 310 DeGuigne Drive Sunnyvale, CA 90486

Attn: H. S. Bailey

General Electric-SCO

P. O. Box 8555

35T15, Bldg. 20

Astro systems

Philadelphia, PA 19101

Attn: J. Chan

General Electric

P. O. Box 8555

Bldg. 100, Rm M2412

Astro Systems

Philadelphia, PA 19101

Attn: J. Hnat

General Electric

P. O. Box 8555

Astro Systems

Philadelphia, PA 19101

Attn: R. D. Casagrande

General Electric

P. O. Box 8555

Astro Systems

Philadelphia, PA 19101

Attn: W. Chiu

Grumman Aerospace Corporation MS B20-05

Bethpage, NY 11714

Attn: J. Belisle

House of Representatives Staff Space and Technology committee 2320 Rayburn Building

Washington, DC 20515

Attn: Tom Weimer 
202 NSC

University of Florida

Gainesville, FL 32611

Attn: N. J. Diaz

International Energy Assoc. Ltd. 1717 Louisiana NE

Suite 202

Albuquerque, NM 87110

Attn: W. H. Roach

International Energy Assoc. Ltd. 1717 Louisiana NE

Suite 202

Albuquerque, NM 87110

Attn: G. B. Varnado

Lawrence Livermore National Lab. P. O. BOX 808

Livermore, CA 94550

Attn: Lynn cleland, MS L-144

Lawrence Livermore National Lab. P. O. Box 808

Livermore, CA 94550

Attn: C. E. Walter, MS L-144

Los Alamos National Laboratory

P. O. Box 1663

Los Alamos, NM 87545

Attn: T. Trapp, MS-E561

Los Alamos National Laboratory

P. O. Box 1663

Los Alamos, NM 87545

Attn: R. Hardie, MS-F611

Los Alamos National Laboratory

P. O. Box 1663

Los Alamos, NM 87545

Attn: C. Bell, MS F611

Los Alamos National Laboratory P. O. Box 1663

Los Alamos, NM 87545

Attn: R. J. Leclaire, MS F611
Los Alamos National Laboratory

P. O. Box 1663

Los Alamos, NM 87545

Attn: S. Jackson, MS-F611

Los Alamos National Laboratory P. O. Box 1663

Los Alamos, NM 87545

Attn: J. Metzger

Los Alamos National Laboratory P. O. Box 1663

Los Alamos, NM 87545

Attn: C. W. Watson, MS $-\mathrm{F} 607$

Los Alamos National Laboratory P. O. Box 1663

Los Alamos, NM 87545

Attn: Don Reid, MS-H811

Los Alamos National Laboratory P. O. Box 1663

Los Alamos, NM 87545

Attn: R. Bohl, MS-K560

Los Alamos National Laboratory P. O. Box 1663

Los Alamos, NM 87545

Attn: D. R. Bennett

Los Alamos National Laboratory P. O. Box 1663

Los Alamos, NM 87545

Attn: W. L. Kirk

Los Alamos National Laboratory P. O. Box 1663

Los Alamos, NM 87545

Attn: M. Merrigan

Los Alamos National Laboratory P. O. Box 1663

Los Alamos, NM 87545

Attn: T. P. Suchocki 
Los Alamos National Laboratory

P. O. Box 1663

Los Alamos, NM 87545

Attn: L. H. Sullivan

Martin Marietta Corp.

P. O. Box 179

Denver, Co 80201

Attn: R. Giellis, MS 0484

Martin Marietta Corp.

P. O. Box 179

Denver, Co 80201

Attn: R. Zercher MSL8060

Massachusetts Institute of Technology

1328 Albany street

Cambridge, MA 02139

Attn: Dr. J. A. Bernard

NASA Lewis Research Center 21000 Brookpark Road Cleveland, OH 44135

Attn: J. Winter, MS 301-5

NASA Lewis Research Center 21000 Brookpark Road

Cleveland, OH 44135

Attn: Barbara McKissock, MS 301-5

NASA Lewis Research Center 21000 Brookpark Road Cleveland, $\mathrm{OH} \quad 44135$

Attn: A. Juhasz

MS 301-5, Rm. 101

NASA Lewis Research Center 21000 Brookpark Road Cleveland, OH 44135

Attn: J. Smith, MS 301-5

NASA Lewis Research Center 21000 Brookpark Road Cleveland, OH 44135

Attn: H. Bloomfield

MS 301-5, Rm. 103
NASA Lewis Research Center 21000 Brookpark Road Cleveland, OH 44135

Attn: Jim Bolander, 3350 Research/Technology Branch

NASA Lewis Research Center 21000 Brookpark Road Cleveland, $\mathrm{OH} \quad 44135$

Attn: Kathleen Batke; 3350 Research/Technology Branch

NASA Lewis Research Center 21000 Brookpark Road Cleveland, $\mathrm{OH} \quad 44135$

Attn: C. Purvis MS 302-1, Rm. 101

NASA Lewis Research Center 21000 Brookpark Road Cleveland, OH 44135

Attn: D. Bents, MS 301-5

NASA Lewis Research Center 21000 Brookpark Road Cleveland, OH 44135

Attn: I. Myers MS 301-2, Rm 116

NASA Lewis Research Center 21000 Brookpark Road Cleveland, OH 44135

Attn: G. Schwarze MS 301-2, Rm. 117

NASA Lewis Research Center 21000 Brookpark Road Cleveland, $\mathrm{OH} \quad 44135$ Attn: J. Sovie MS 301-5, Rm. 105

National Research Council Energy Engineering Board Commission on Engineering and Technical systems 2101 Constitution Avenue Washington, DC 20418

Attn: $R$. Cohen 
Naval Research Laboratory washington, DC 20375-5000 Attn: R. L. Eilbert

Naval Research Laboratory Washington, DC 20375-5000 Attn: I. M. Vitkovitsky

Naval Space Command Dahlgren, VA 22448 Attn: Commander R. Nosco

Naval space Command N5

Dahlgren, VA 22448

Attn: Maj. J. Wiley

Naval Space Command Dahlgren, VA 22448

Attn: Mr. B. Meyers

Naval Surface Weapons Center

Dahlgren, VA 22448-5000

Attn: R. Gripshoven-F12

Naval Surface Weapons Center Dahlgren, VA 22448-5000

Attn: R. Dewitt-F12

White Oak Laboratory

Silver Springs, MD 20903-500

MC R-42

Attn: B. Maccabee

Nichols Research Corp. 2340 Alamo street, SE

Suite 105

Albuquerque, NM 87106

Attn: $R$. Weed

Oak Ridge National Laboratory P. O. BoX Y

Bldg. 9201-3, MS-7

Oak Ridge, TN 37831

Attn: J. P. Nichols
Oak Ridge National Laboratory P. O. BoX Y

Bldg. 9201-3, MS-7

Oak Ridge, TN 37831

Attn: D. Bartine

Oak Ridge National Laboratory P. O. BoX X

Oak Ridge, TN 37831

Attn: H. W. Hoffman

Oak Ridge National Laboratory P. O. BOX Y

Bldg. 9201-3, MS-7

Oak Ridge, TN 37831

Attn: R. H. Cooper, Jr.

Oak Ridge National Laboratory P. O. BOX Y

Bldg. 9201-3, MS-7

Oak Ridge, TN 37831

Attn: J. C. Moyers

Oak Ridge National Laboratory P. O. BoX $Y$

Oak Ridge, TN 37831

Attn: M. Olszewski

Oak Ridge National Laboratory P. O. BoX Y

Bldg. 9201-3, MS-7

Oak Ridge, TN 37831

Attn: M. Siman-Tov

Oak Ridge National Laboratory

P. O. Box $\mathrm{Y}$

Bldg. 9201-3, MS-7

Oak Ridge, TN 37831

Attn: F. W. Wiffen

RADC/OCTP

Griffiss AFB

New York 13441

Attn: R. Gray 
Riverside Research Institute 1701 No. Ft. Meyers Drive Suite 700

Arlington, VA 22209

Attn: J. Feig

Science \& Engineering Associates 6301 Indian School Road, NE Albuquerque, NM 87110

Attn: G. L. Zigler

SDI Organization

The Pentagon

Washington, DC 20301-7100

Attn: $R$. Verga

SDI Organization

The Pentagon

Washington, DC 20301-7100

Attn: D. Buden

SDI/SLKT

The Pentagon

1717 H. St. NW

Washington, D. C. 20301

Attn: C. Northrup

SDIO/DE

Washington, DC 20301-7100

Attn: Dr. R. Hammond

SDIO/IST

Washington, DC 20301-7100

Attn: Dr. L. Cavery

SDIO/KE

The Pentagon

Washington, DC 20301-7100

Attn: Col. R. Ross

SDIO

The Pentagon

Washington, DC 20301-7100

Attn: Maj. R. X. Lenard
SDIO/SATKA

Washington, DC 20301-7100

Attn: Col. Garry Schnelzer

SDIO/SY

Washington, DC 20301-7100

Attn: Dr. C. Sharn

SDIO/SY

Washington, DC 20301-7100

Attn: Col. J. Schofield

SDIO/SY

Washington, DC 20301-7100

Attn: Col. J. Graham

SDIO/SY

Washington, DC 20301-7100

Attn: Capt. J. Doegan

Space Power, Inc.

1977 Councourse Dr.

San Jose, CA 95131

Attn: J. R. Wetch

State University of New York at Buffalo

Dept. of Elec. Engineering

312 Bonner Avenue

Buffalo, NY 14260

Attn: Jim Sargeant

\section{TRW}

One Space Park

Redondo Beach, CA 90278

Attn: R. L. Hammel

TRW

One Space Park

Redondo Beach, CA 90278

Attn: T. Fitzgerald

TRW

One Space Park

Redondo Beach, CA 90278

Attn: James Garner 
One Space Park

Redondo Beach, CA 90278

Attn: B. Glasgow

TRW

One Space Park

Redondo Beach, CA 90278

Attn: A. D. Schoenfeld

Teledyne Brown Engineering

Cummings Research Park

Huntsville, AL 35807

Attn: Dan DeLong

Texas A\&M University

Nuclear Engineering Dept.

College station, $\mathrm{TX}$ 77843-3133

Attn: F. Best

Texas Tech. University

Dept. of Electrical Engr.

Lubbock, TX 79409

Attn: Dr. w. Portnoy

U. S. Army ARDC

Building 329

Picatinny Arsenal

New Jersey 87806-5000

Attn: SMCAR-SSA-E

U. S. Army Belvoir RDE Center Fort Belvoir, VA 22060-5606

Attn: Dr. L. Amstutz-STRABE-FGE

U. S. Army Lab. Com.

SLKET/ML

Pulse Power Technology Branch

Fort Monmouth, NJ 07703-5000

Attn: S. Levy

U. S. Army Lab. Com.

SLKET/ML

Pulse Power Technology Branch

Fort Monmouth, NJ 07703-5000

Attn: N. Wilson
U. S. Army Strategic Defense Com. 106 Wynn Drive

Huntsville, AL 35807

Attn: C. Cooper

U. S. Army strategic Defense Com. 106 Wynn Drive

Huntsville, AL 35807

Attn: G. Ealin

U. S. Army Strategic Defense Com. 106 Wynn Drive

Huntsville, AL 35807

Attn: R. Hall

U. S. Army Strategic Defense Com. 106 Wynn Drive

Huntsville, AL 35807

Attn: E. L. Wilkinson

U. S. Army Strategic Defense Com. 106 Wynn Drive

Huntsville, AL 35807

Attn: D. Bouska

U. S. Army Strategic Defense Com. 106 Wynn Drive

Huntsville, AL 35807

Attn: w. Sullivan

U. S. Army Strategic Defense Com. 106 Wynn Drive

Huntsville, AL 35807

Attn: F. King

U. S. Department of Energy

Chicago Operations office

9800 S. Cass Avenue

Argonne, IL 60439

Attn: J. L. Hooper

U. S. Department of Energy

NE-52

GTN

Germantown, MD 20545

Attn: J. Warren 
U. S. Department of Energy

NE-54

F415/GTN

Germantown, MD 20545

Attn: E. Wahlquist

U. S. Department of Energy

NE-521

Germantown, MD 20874

Attn: D. Bennett

San Francisco Operations office 1333 Broadway Ave, Oakland, CA 94612

Attn: J. K. Hartman

U. S. Department of Energy

SAN - ACR Division

1333 Broadway

Oakland, CA 94612

Attn: J. Krupa

U. S. Department of Energy

SAN - ACR Division

1333 Broadway

Oakland, CA 94612

Attn: $w$. Lambert

U. S. Department of Energy

SAN - ACR Division

1333 Broadway

Oakland, CA 94612

Attn: J. Zielinski

U. S. Department of Energy

Pittsburgh Energy Tech. Center

P.O. Box 18288

Pittsburgh, PA 15236

Attn: G. Staats $(P M-20)$

U. S. Department of Energy

NE-54

Washington, DC 20545

Attn: I. Helms
U. S. Department of Energy Oak Ridge Operations office P.O. BoX E

Oak Ridge, TN 37830

Attn: E. E. Hoffman

U. S. Department of Energy

Washington, DC 20545

Attn: S. J. Lanes

U. S. Department of Energy

MA 206

Washington, DC 20545

Attn: $J . P$. Lee

U. S. Department of Energy

San Francisco Operations office 1333 Broadway Avenue

Oakland, CA 94612

Attn: S. L. Samuelson

U. S. Department of Energy

ALO/ETD

P.O. Box 5400

Albuquerque, New Mexico 87115

Attn: R. L. Holton

U. S. Department of Energy

ALO/ETD

P.O. Box 5400

Albuquerque, New Mexico 87115

Attn: c. Quinn

U. S. Department of Energy/Idaho 785 DOE Place

Idaho Falls, ID 83402

Attn: P. J. Dirkmaat

United Technologies International Fuel Cells 195 Governor's Highway South windsor, CT 06074

Attn: D. McVay 
United Technologies

International Fuel cells

195 Governor's Highway

South windsor, CT 06074

Attn: J. L. Preston, Jr.

United Technologies

International Fuel cells

195 Governor's Highway

South windsor, CT 06074

Attn: J. C. Trocciola

University of Missouri - Rolla

220 Engineering Research Lab

Rolla, MO 65401-0249

Attn: A. S. Kumar

University of New Mexico

Chemical and Nuclear Engineering

Department

Albuquerque, NM 87131

Attn: M. El-Genk

University of Wisconsin

Fussion Technology Institute

1500 Johnson Drive

Madison, WI 53706-1687

Attn: Gerald Kulcinski

W. J. Schafer Associates

1901 No. Ft. Myers Drive

Suite 800

Arlington, VA 22209

Attn: P. Mace

W. J. Schafer Associates 1901 No. Ft. Myers Drive suite 800

Arlington, VA 22209

Attn: Ormon Bassett

W. J. Schafer Associates 1901 No. Ft. Myers Drive

Suite 800

Arlington, VA 22209

Attn: M. Nikolich
W. J. Schafer Associates 1901 No. Ft. Myers Drive Suite 800

Arlington, VA 22209

Attn: J. Crissey

W. J. Schafer Associates

2000 Randolph Road, SE \#205

Albuquerque, NM 87106

Attn: D. C. Straw

W. J. Schafer Associates 1901 No. Ft. Myers Drive Suite 800

Arlington, VA 22209

Attn: A. K. Hyder

Westinghouse Electric

P. O. Box 158

Madison, PA 15663-0158

Attn: J. Chi

Westinghouse

Advanced Energy Systems Division Manager, Space \& Defense Program Route 70, Madison Exit

Madison, PA 15663

Attn: J. F. Wett

Westinghouse

Advanced Energy Systems Division

P.O. Box 158

Madison, PA 15663

Attn: Dr. J. W. H. Chi

1310 Beulah Road

Bldg. 501-3Y56

Pittsburgh, PA 15235

Attn: J. R. Repp

Westinghouse R\&D

1310 Beulah Road

Bldg. 501-3Y56

Pittsburgh, PA 15235

Attn: L. Long 


\author{
Westinghouse R\&D \\ 1310 Beulah Road \\ Bldg. 501-3Y56 \\ Pittsburgh, PA 15235 \\ Attn: Owen Taylor \\ Westinghouse Advanced Energy \\ Systems Division \\ P.O. Box 158 \\ Madison, PA 15663 \\ Attn: G. Farbman \\ Westinghouse Hanford Company \\ P. O. Box 1970 \\ Richland, WA 99352 \\ Attn: D. S. Dutt \\ Westinghouse Hanford Company \\ P. O. Box 1970 \\ Richland, WA 99352 \\ Attn: B. J. Makenas
}




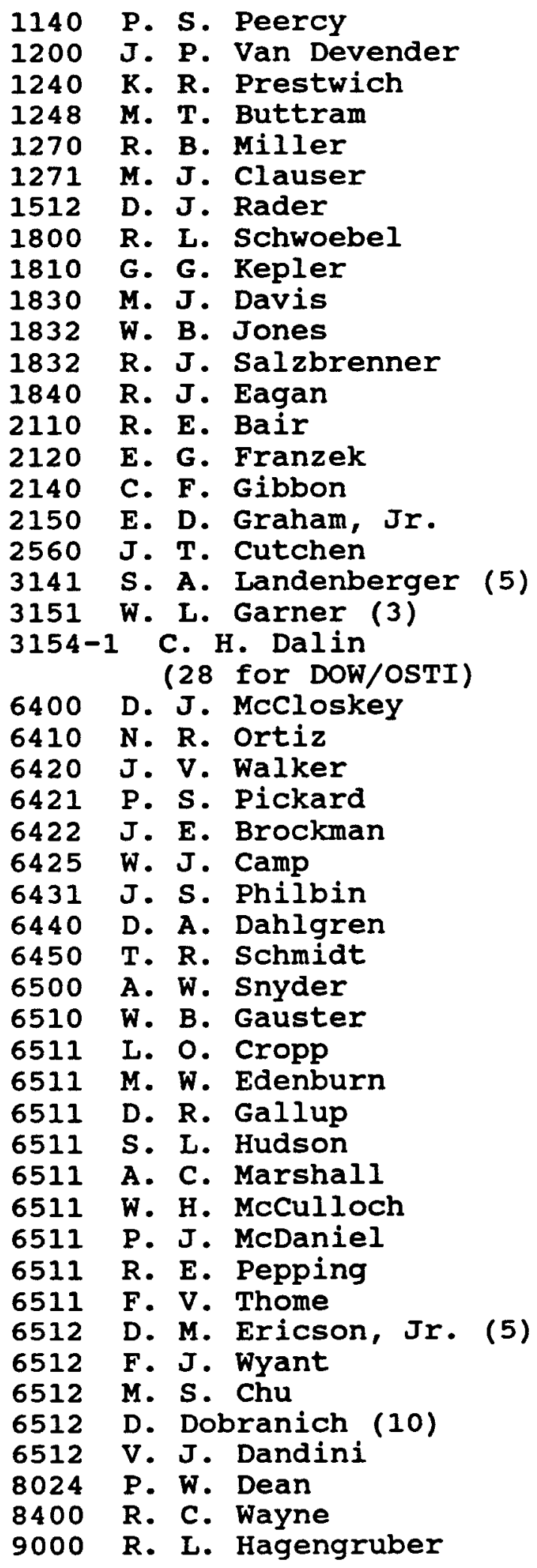

9010 W. C. Hines

9012 J. W. Keizur

9012 L. W. Connell

9012 R. M. Zazworski

9100 R. G. Clem

9110 P. A. Stokes

9140 D. J. Rigali 